\title{
Timing Under a Unified Wealth Transfer Tax
}

\author{
Theodore S. Sims $\dagger$
}

The United States taxes gifts made while an individual is living more leniently than it taxes wealth transfers at death. Although in some measure this disparity has existed since the enactment of the modern estate and gift taxes in $1916^{1}$ and $1932,{ }^{2}$ it was significantly narrowed by the Tax Reform Act of 1976 (the 1976 Act). ${ }^{3}$ That statute replaced the separate gift and estate taxes with

† Associate Professor of Law, George Washington University National Law Center. In part the stimulus for pursuing the line of analysis developed in this article was a conversation with Professor Joseph Isenbergh of the University of Chicago Law School. The author would like to express his appreciation for helpful comments on earlier versions of this paper by John T. Adney and Daniel I. Halperin, by his colleagues Peter Raven-Hansen, Roger E. Schechter and Roger Trangsrud, and, in particular, by James S. Halpern. What follows is dedicated to Professor Halperin, and to Seymour Fiekowsky of the United States Treasury Office of Tax Analysis.

${ }^{1}$ Revenue Act of 1916, Pub. L. No. 64-271, tit. II, $\S \S 200-212,39$ Stat. 756, 777-80 (current version at I.R.C. $\$ \S 2001-2057$ (1982)).

2 Revenue Act of 1932, Pub. L. No. 72-154, tit. III, $\S \S 501-532,47$ Stat. 169, 245-59 (current version at I.R.C. $\$ \S 2501-2524$ (1982)).

s Tax Reform Act of 1976, Pub. L. No. 94-455, tit. XX, § 2001(a)(1), 90 Stat. 1520, 1846-48 (codified as amended in scattered sections of I.R.C. (1982)). Before 1976, lifetime transfers subject to the gift tax, like transfers at death subject to the estate tax, were taxed at steeply graduated rates. The gift tax rates, however, were applied independently of the estate tax rates, so that, regardless of how much wealth an individual had transferred by lifetime gift, the first dollar of his taxable estate was taxed at the lowest marginal estate tax rate. In addition, the exemption for the first $\$ 30,000$ of gifts made during a donor's lifetime was available in addition to the $\$ 60,000$ estate tax exemption, and nominal gift tax rates were fixed at three-quarters of the nominal estate tax rates. See Kurtz \& Surrey, Reform of Death and Gift Taxes: The 1969 Treasury Proposals, the Criticisms, and a Rebuttal, 70 Colum. L. REv. 1365, 1371-72 (1970). This dual tax structure conferred substantial advantages on the judicious division of wealth transmission between lifetime gifts and transfers at death and was the subject of persistent criticism. See House Comm. on Ways and Mrans and Senate Comm. on Finance, 91st Cong., 1st Sess., Tax Rerorm Studies and Proposals United States Treasury Department 329-409 (Comm. Print 1969) [hereinafter cited as Treasury Proposals], reprinted in relevant part in Stapg of the House Comm. on Ways and Means, 94th Cong., 2D Sess., Background Matzrials on Estate and Girt Taxation 183, 231-309 (Comm. Print 1976) [hereinafter cited as 1976 Stafr Materiazs]; Amerucan LAW Institute, Federat Estate and Gift TAXation (1969) [hereinafter cited as ALI Study], reprinted in part in 1976 Staff Materials, supra, at 311-79; C. Shoup, Federal Estate and Gift Taxes (1966); Treasury Department Advisory Committee \& Office of Tax Legislative Counsel, Federal Estate and Gift Taxes: A Proposal por Integration and for Correlation with the Income Tax (1947); Casner, American Law Institute Fed- 
a regime that taxes the cumulative total of an individual's lifetime taxable gifts and his taxable estate at death, under a single (or "unified") graduated table of rates." Nevertheless, there remains a signficant difference between the taxation of gifts and estates. Under existing law, the gift tax base systematically excludes the transfer tax paid, whereas the estate tax base does not.. As a result, effective gift tax rates are systematically lower than estate tax rates, ${ }^{6}$ and the system that we actually have is something less than

eral Estate and Gift Tax Project, 22 TAx L. REv. 515 (1967); Dewind, The Approaching Crisis in Federal Estate and Gift Taxation, 38 CALIF. L. Rev. 79 (1950); Eisenstein, The Rise and Decline of the Estate Tax, 11 Tax L. Rev. 223 (1956); Surrey, An Intoduction to Revision of the Federal Estate and Gift Taxes, 38 CalIF. L. REv. 1 (1950); Westfall, Revitalizing the Federal Estate and Gift Taxes, 83 HARv. L. REv. 986 (1970). The most persistent criticisms of the pre-1976 system were: first, that it placed an undue premium on techniques for taking advantage of more lenient gift taxation; second, that congressional efforts to forestall untrammeled access to those techniques greatly complicated the estate tax; and third, that the advantageous treatment it conferred on lifetime gifts operated to favor the extremely wealthy, who could afford to part with some of their wealth while living, over those who, while sufficiently well-to-do to be subject to the wealth-transfer taxes, were insufficiently wealthy to part with what they had while they were alive. See, e.g., TrEasurY Proposals, supra, at 351-55, reprinted in 1976 Staps Materials, supra, at 251-55; C. Shoup, supra, at 14-17, 26-28, 127-28; Casner, supra, at 533; Dewind, supra, at 82-85, 93-94; Eisenstein, supra, at 244-45; Kurtz \& Surrey, supra, at 1368, 1371-76; Surrey, supra, at 910.

I.R.C. $\$ \S 2001$ (b)-(c), 2502(a) (1982). The unified rate structure operates with respect to lifetime gifts by adding each successive taxable gift to the sum of all prior taxable gifts, ascertaining a "tentative tax" on the total under the graduated rate table contained in I.R.C. $\S 2001$ (c) (1982), and then subtracting from that "tentative tax" the sum of the gift taxes already paid with respect to prior taxable transfers. I.R.C. $\S 2502$ (a) (1982). The technique of cumulating each gift with all prior gifts for purposes of computing the "tentative tax" ensures taxation of each incremental wealth transfer at the proper marginal rate. The provision for subtracting gift taxes already paid from the "tentative tax" ensures that no gift is taxed more than once.

At death, a "tentative tax" is again computed on the sum of the decedent's aggregate lifetime taxable gifts-referred to as the decedent's "adjusted taxable gifts"-plus the decedent's taxable estate, from which there is subtracted the sum of all gift taxes paid. I.R.C. \$ 2001(b) (1982). Once again, the technique of cumulating, computing a "tentative tax," and then subtracting gift taxes paid, operates both to tax the estate at the proper marginal rate (taking into account the amount of the decedent's taxable lifetime gifts), and to forestall taxation of any wealth transfer under both the gift and estate taxes.

The gift and estate taxes now are subject to a single, overall exemption, effectuated through a "unified credit" against tax. I.R.C. $\$ \S 2010$ (a) (estate tax), 2505(a) (gift tax) (1982).

s See, e.g., S. Surrey, W. Warren, P. McDantel \& H. Gutman, Federal Wealth Transfer Taxation 267-271 (2d ed. 1982); Kurtz \& Surrey, supra note 3, at 1373.

- In reality, lifetime giving is favored in yet another, cumulatively significant way. Each individual is allowed an "annual exclusion" for gifts of up to $\$ 10,000$ to each donee. See I.R.C. \& 2503(b) (1982). The original rationale for an annual exclusion was to avoid the need for payment of tax in connection with modest, recurring gifts. See H. R. REP. No. 708, 72d Cong., 1st Sess. 29 (1982); cf. Dickman v. Commissioner, 104 S. Ct. 1086, 1093 (1984) (holding that interest-free loans give rise to gift tax on the interest foregone, noting that existing 
a truly "unified" wealth-transfer tax.

What follows is an appraisal of two different means of rectifying the remaining discrepancy between the taxation of gifts and estates. One approach would correct for the difference in tax bases by adjusting the transferor's estate for tax purposes. This approach is presaged by section 2035(c) of the Internal Revenue Code of 1954 (the Code), added by the 1976 Act, which prescribes just such an adjustment for taxable gifts made within three years before the transferor's death. ${ }^{7}$ The other approach would modify the way in which we now tax lifetime gifts. A modification of this sort was proposed by the Treasury Department in 1969, but has never been adopted by Congress. ${ }^{8}$ Either change would eliminate the existing difference in the treatment of taxable gifts and estates, at least in nominal terms, ${ }^{\circ}$ and in some sense each would thereby "unify" the gift and estate taxes. But the timing of the adjustment under the two approaches differs. Consequently, a comparision of the two leads to an examination of some implications of transfer tax timing. ${ }^{10}$

It is not clear how receptive Congress currently would be to creating a truly unified gift and estate tax. In the eyes of many, the 1976 legislation significantly improved the structure of the sys-

"exclusions, exceptions, and credits clearly absorb . . . de minimis gifts"). Nevertheless, the size of the exclusion, which was increased from $\$ 3,000$ to $\$ 10,000$ by $\$ 441$ (a) of the Economic Recovery Act of 1981, Pub. L. No. 97-34, tit. IV, § 441(a), 95 Stat. 172, 319 (codified at I.R.C. § 2503(b) (1982)), and the fact that it applies per donee each year, means that quite substantial amounts can be transmitted through recurring annual gifts.

What is more, the looming $\$ 600,000$ basic gift and estate tax exemption, combined with an unlimited marital deduction, see infra note 12, makes the universe of decedents sufficiently wealthy to be subject to the estate tax quite small. See Gutman, Reforming Federal Wealth Transfer Taxes After ERTA, 69 VA. L. REv. 1187, 1207-08 (1983). For these fortunate (or unfortunate) individuals, however, the difference between the taxation of estates and taxable gifts can significantly influence transfer tax planning. See infra Part II.

${ }^{7}$ I.R.C. $\S 2035$ (c) (1982) (added to the Code by the Tax Reform Act of 1976, Pub. L. No. 94-455, tit. XX, $\S 2001$ (a)(5), 90 Stat. 1520, 1848-49). For a discussion of the origins and the significance of $\S 2035$ (c), see infra notes 103-07 and accompanying text.

8 Treasury Proposals, supra note 3, at 355, 369, reprinted in 1976 Staff Materials, supra note 3 , at 255,269 . For a discussion of the modification proposed by the Treasury, see infra notes 98-102 and accompanying text.

- That is, either approach would restore the same number of dollars to the transfer-tax base, disregarding the time at which some part of those dollars was taxed, see infra Part III, and any implications of that difference in timing. See infra Part IV.

10 The literature on the implications of timing in the transfer tax context is virtually nonexistent. By contrast, the literature concerning timing under the income tax is too voluminous even to mention. This difference may reflect the relative contribution to federal revenues of the wealth transfer taxes and the income tax. See Graetz, To Praise the Estate Tax, Not to Bury It, 93 YaLE L.J. 259, 263-69 (1983). 
tem. ${ }^{11}$ Subsequently, as part of the tax reductions enacted by the Economic Recovery Tax Act of 1981 (the 1981 Act), the basic transfer tax exemption was trebled and the degree of graduation in the transfer tax rates was reduced by nearly one-third. ${ }^{12}$ Structural reform of the wealth transfer taxes thus was followed shortly by a sharp reduction in their impact. Although in 1981 the Reagan Administration was at least tolerant of these developments, it has resisted further efforts to weaken the taxes. ${ }^{13}$ The import of this recent activity for the future of transfer tax legislation is anyone's guess.

The direction in which the transfer tax system ought to evolve is likewise unclear. The estate tax enacted in 1916 was the product of both a wartime need for revenues and congressional reluctance to enlarge the extent to which the federal government was financed by tariffs and other taxes on consumption. ${ }^{14}$ The gift tax was later enacted to rectify the nearly wholesale evisceration of the estate tax at the hands of the Supreme Court. ${ }^{16}$ Apart from adding modestly to federal revenues, the rationale for these taxes never has been self-evident. ${ }^{16}$ Lack of clarity about objectives tends to promote uncertainty about the proper contours of the tax.

Against this background of general uncertainty both as to

${ }^{11}$ See, e.g., S. Surrey, W. WARren, P. McDaniel \& H. GuTman, supra note 5, at 26871; Graetz, supra note 10, at 260.

12 Economic Recovery Tax Act of 1981, Pub. L. No. 97-34, tit. IV, $\$ \S 401(\mathrm{a}), 402$ (a), 95 Stat. 122, 299, 300 (codified at I.R.C. $\$ \S 2010(a), 2001$ (c) (1982)). The 1981 Act increased the "unified credit," through which the basic exemption from tax is effectuated, see supra note 4 , from $\$ 47,000$ to $\$ 192,800$, raising the effective exemption (or "exemption equivalent") from $\$ 175,000$ to $\$ 600,000$. It also reduced the top marginal rate from $70 \%$ to $50 \%$. Both the increase in exemption and the reduction in rates were phased in over several years. I.R.C. $\$ \S$ 2010(b), 2001(c)(2) (1982). Finally, the 1981 Act repealed the pre-existing limits on both the gift and estate tax marital deduction. See Economic Recovery Tax Act of 1981, Pub. L. No.

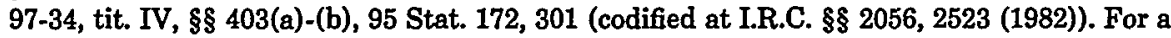
discussion of the 1981 Act, see Graetz, supra note 10, at 262-63.

1s See Estate Tax Issues-1983: Hearings Before the Subcomm. on Estate and Gift Taxation of the Senate Comm. on Finance, 98th Cong., 1st Sess. 55-67 (1983) (statement of Robert G. Woodward, Acting Tax Legislative Counsel, U.S. Treasury Dep't) [hereinafter cited as 1983 Senate Hearings]. Fluctuation in sentiment toward these taxes has a long history. See Eisenstein, supra note 3, at 224-38.

14 See H.R. REp. No. 922, 64th Cong., 1st Sess., 2-3 (1916); see also Eisenstein, supra note 3 , at 230 (discussing H.R. REP. No. 922).

is See infra notes 51, 62 .

16 For an entertaining capsule review of the history through 1950, see Eisenstein, supra note 3, at 224-38; see also C. SHoup, supra note 3, at 101-06; Gutman, supra note 6, at 118789; Kurtz \& Surrey, supra note 3, at 1367 (all considering the aims of transfer taxation). The view has begun to emerge recently that a wealth transfer tax can properly serve to shore up the progressivity of the income tax. See Graetz, supra note 10, at 271-73; Gutman, supra note 6, at 1193-97. 
what is appropriate and what likely, the following discussion assumes that we shall retain the gift and estate taxes in roughly their current form for the foreseeable future. Given that assumption, achieving a unification of the gift and estate tax bases is desirable. ${ }^{17}$ There seems to be no compelling reason to tax lifetime transfers more leniently than transfers at death, ${ }^{18}$ and eliminating the difference could pave the way for substantial estate tax simplification. ${ }^{19}$ The enactment of section 2035 (c) ${ }^{20}$ in 1976 was a step in the right direction. This article examines whether it was the right step to take.

Using numerical examples, Part I identifies in concrete terms the remaining difference between the treatment of taxable gifts and taxable estates, assuming for simplicity a world with a single transfer tax rate. Part II examines briefly some of the complicating features of our wealth-transfer taxes that are more or less directly attributable to differences in the way we historically have taxed gifts and estates. Part III describes what appear to be the two principal means of rectifying the difference, and Part IV compares their operation. The conclusion emerges from Parts III and IV that, if real unification of the transfer taxes is the objective, the step actually taken by Congress in 1976 was in principle the less desirable of the alternatives. Part V then develops a method by which the alternative advocated by the Treasury in 1969-socalled "grossed-up" taxation of gifts-can be easily implemented, even in a world with graduated transfer tax rates.

In many ways the issues can more clearly and generally be posed and analyzed through simple algebra. Rather than cluttering the text with equations, however, I have elected to recapitulate the central analysis algebraically in an appendix. For those already familiar with the problem and possessing the patience to deal with the algebra, an immediate detour to Appendix A may be appropriate.

17 For simplicity of exposition, this discussion is confined to the gift and estate taxes, putting aside the so-called generation-skipping transfer tax, which since its enactment in 1976 has been embroiled in controversy. See, e.g., 1983 Senate Hearings, supra note 13, at 56-63. Just how the analysis that follows might apply to that tax would depend on the form in which the tax emerges from the controversy.

${ }^{18}$ See, e.g., Dewind, supra note 3, at 93-94, 106-07; Wales, Consistency in Taxes-The Rationale of Integration and Correlation, 3 TAX L. REv. 173, 176-77 (1947). A contrary viewpoint is expressed by the authorities cited infra note 113.

10 See infra notes $63-95$ and accompanying text.

${ }^{20}$ I.R.C. $\S 2035$ (c) (1982), discussed supra note 7 and accompanying text; infra notes 103-07 and accompanying text. 


\section{The Difference Between Gift and Estate Taxation}

More lenient taxation of lifetime gifts, even under uniform gift and estate tax rates, arises from a disparity in the tax bases to which those rates are applied. The estate tax base-the "taxable estate"-includes the entire stock of wealth, after allowable deductions, left by an individual at death. ${ }^{21}$ Tax is levied on the taxable estate in its entirety. ${ }^{22} \mathrm{~A}$ part of the estate is then paid as tax, while the balance-which we might refer to as the "estate after tax"-is distributed to the designated recipients. ${ }^{23}$ The estate tax is therefore imposed both on what passes to private distributees and what must be paid as tax. ${ }^{24}$

With lifetime gifts, the occasion for imposing tax is the voluntary conveyance of part of the transferor's wealth to a private recipient. The gift tax base-the "taxable gift"-is the value of the private wealth transfer, excluding what the transferor then must pay to the government in tax. ${ }^{25}$ The gift tax base thus corresponds with the "estate after tax" in the case of a transfer at death, not with the "taxable estate." For convenience, the estate tax base may

21 I.R.C. $\$ \S 2032,2033,2051$ (1982). Assets not actually in the decedent's possession at death also may be included in his estate. See, e.g., id. $\$ \$ 2036-2038$ (returning to the taxable estate lifetime gifts with retained powers or interests), discussed infra notes 52-74 and accompanying text; $\$ 2041$ (property subject to a power of appointment).

12 I.R.C. \$ 2001(a) (1982). There are allowed, against the estate tax as computed under \$2001(a), not only the "unified credit" through which the basic exemption is given effect, see supra note 4, but also a credit for state death taxes, I.R.C. $\$ 2011$ (1982), a credit for transfer taxes imposed by reason of wealth transfers to the decedent close to the date of decedent's death, id. $\S 2013$, and a credit for certain foreign death taxes, id. $\$ 2014$.

29 The concept of an "estate after tax," used here to denote an individual's transferable wealth after payment of estate tax, is not a statutory term of art, and is only loosely descriptive. Strictly speaking, an individual's transferable wealth may exceed the difference between his (or her) "taxable estate" and the estate tax payable. For example, gifts to charitable recipients may be deductible under I.R.C. $\$ 2055$ (1982) in computing the decedent's "taxable estate," even though the amount for which a deduction is allowed may constitute value in the estate that is actually transmitted to the charity. Similarly, the fair market value of assets available for transfer to noncharitable recipients may exceed the amount of the "taxable estate" minus the estate tax paid. This may occur, for example, where the assets of the estate include property eligible for "special use" valuation under I.R.C. \& 2032A (1982).

To simplify the analysis, I assume throughout this article that the decedent's "taxable estate" corresponds to his or her transferable wealth before estate tax, and that the entire "estate after tax" is to be distributed to private, noncharitable recipients.

24 See S. Surrey, W. Warren, P. McDanirl \& H. Gutman, supra note 5, at 269; Gutman, supra note 6, at 1249 \& n.185; Kurtz \& Surrey, supra note 3, at 1372-73.

2s I.R.C. $\$ \S 2501(a)(1), 2503(a), 2512(a)$ (1982). The obligation to pay gift tax is the transferor's. Efforts to arrange for satisfaction of gift taxes by the recipient of a gift have led to vexing income tax issues only recently (and only partly) resolved by the Supreme Court. See Diedrich v. Commissioner, 457 U.S. 191, 194-200 (1982). 
be described as "tax-inclusive," whereas the gift tax base is "taxexclusive";28 or, as it is sometimes put colloquially, the gift tax does not impose a "tax on the tax." ${ }^{27}$ The result is that, for equivalent after-tax transfers, the gift tax base is systematically smaller than the estate tax base. Thus, where nominally identical tax rates apply to apparently equivalent transfers, a lifetime wealth transfer is taxed at a lower effective rate than is a comparable transfer at death. ${ }^{28}$

Two simple examples serve to illustrate this difference. Each assumes a transferor $(T)$ who has wealth of $\$ 100$ available for transfer, and the levy of a $40 \%$ tax on each dollar transferred.

\section{Example 1}

If $T$ 's wealth of $\$ 100$ were transferred at death, $T$ 's taxable estate would be $\$ 100$, and the tax at $40 \%$ would be $\$ 40$. T's estate after tax-the net private wealth transfer-would be $\$ 100$ minus $\$ 40$, or $\$ 60$.

Example 2 examines the consequence to $T$ of making a lifetime gift equal to the $\$ 60$ estate after tax in Example 1.

\section{Example 2}

If $\$ 60$ were transferred by lifetime gift, the taxable gift would be $\$ 60$ and the gift tax, at $40 \%$, would be $\$ 24$.

In Example 2, the transfer tax associated with a $\$ 60$ after-tax transfer is $\$ 24$, rather than $\$ 40$ as in Example 1, even though the nominal tax rate is $40 \%$ in each case. ${ }^{29}$ Expressed consistently as percentages of the sum of the private wealth transfer plus wealth transfer tax-that is, compared on a "tax-inclusive" basis-the effective estate tax rate is $40 \%(\$ 40 / \$ 100)$, whereas the effective gift tax rate is only $28.6 \%(\$ 24 / \$ 84)$. A comparable relationship holds for all positive nominal transfer tax rates. ${ }^{30}$

${ }^{28}$ The terminology is borrowed from Graetz, Implementing a Progressive Consumption Tax, 92 HaRv. L. REv. 1575, 1582-83 (1979).

${ }^{27}$ See, e.g., Casner, supra note 3, at 534; Dewind, supra note 3, at 105; Eisenstein, supra note 3, at 244; authorities cited supra note 24 .

${ }^{28}$ See, e.g., Kurtz \& Surrey, supra note 3, at 1373.

20 To put the comparison differently, if $T$ wished to dispose of the entire $\$ 100$ by gift, he could transfer $\$ 71.43$. The gift tax, at $40 \%$, would be $\$ 28.57$, and the total tax and transfer would add up to $\$ 100$. A lifetime gift of fully $\$ 100$ would require the transferor to possess $\$ 140$ in all, so as to be able to satisfy a gift tax liability of $\$ 40$. Regardless of whether the gift is of $\$ 60, \$ 71.43$ or $\$ 100$, the effective gift tax rate is unaffected. See infra note 30 .

so Compared in this fashion the effective gift tax rate will equal $t /(1+t)$ where the effective estate tax rate is $t$. See Graetz, supra note 26, at $1583 \mathrm{n} .25$ (deriving formula); infra note 99 and accompanying text; see also Kurtz \& Surrey, supra note 3, at 1373 (estate 
As first enacted in $1932,{ }^{31}$ the gift tax was made explicitly less onerous than the estate tax, ${ }^{32}$ and it remained so for over forty years. The advent of a unified rate schedule and exemption in 1976 eliminated most of the explicit advantages. ${ }^{33}$ But, as illustrated by Examples 1 and 2, these changes simply reduced the size of the overall advantage to lifetime giving. ${ }^{34}$

No explanation is given by the reports on the Revenue Act of 1932 for the original enactment of a gift tax with a base that differed from the estate tax base. ${ }^{35}$ One surmises that, when Congress was fashioning the estate tax in $1916,{ }^{36}$ the decedent's aggregate estate, after allowable deductions but before extraction of the tax, fell to hand as the most natural object of the levy. ${ }^{37}$ In contrast, the most readily observable aspect of a lifetime gift is the size of the private wealth transfer. Simple convenience, then, originally may have accounted for the difference. Even if Congress had thought about the problem, it might not have been overly concerned in 1932, since it was determined to tax lifetime gifts more leniently than estates in any event. ${ }^{38}$ Whatever the original reasons, the disparity survives to this day. The congressional willingness to make substantial revisions to the gift and estate taxes in 1976 did not extend to eliminating the difference in the tax bases. ${ }^{39}$

tax rates applied to aggregate estate; gift tax rates applied to net transfer).

31 A gift tax law with almost no teeth was enacted in 1924, Revenue Act of 1924, Pub. L. No. $68-176$, tit. III, $\$ \S 319-324,43$ Stat. 253, 313-16, but was repealed by the Revenue Act of 1926, Pub. L. No. 69-20, tit. XII, $\$ 1200$, 44 Stat. (pt. 2) 125-26. For an historical account of this legislation, see Eisenstein, supra note 3, at 232-34. The current gift tax statute is codified at I.R.C. $\$ \S 2501-2524$ (1982).

s2 See Revenue Act of 1932, Pub. L. No. 72-154, tit. II, \& 401(b), 47 Stat. 169, 243 (estate tax rate schedule beginning at $1 \%$ on net estates not in excess of $\$ 10,000$ ); id. tit. III, $\S 502,47$ Stat. 169, 246 (gift tax rate schedule beginning at three-quarters of $1 \%$ on net gifts not in excess of $\$ 10,000)$. The legislative history of these provisions acknowledges the difference. See H.R. REp. No. 708, 72d Cong., 1st Sess. 29 (1932); S. Rep. No. 665, 72d Cong., 1st Sess. 11 (1932).

2s The enactment of the unified rate schedule and unified credit deprived transferors of the ability to secure the benefit of separate gift and estate tax exemptions and to secure taxation of transfers at lower marginal rates, through the use of lifetime gifts. See S. SurREY, W. WARREN, P. MCDANIEL \& H. GuTMAN, supra note 5, at 268-71; supra notes 3-4.

34 For further elaboration of this point, see infra notes 93-94 and accompanying text.

ss See H.R. Rep. No. 708, 72d Cong., Ist Sess. $27-30$ (1932); S. Rep. No. 665, 72d Cong., 1st Sess. 11, 38-41 (1932).

so See supra note 1 and accompanying text.

37 See H.R. REP. No. 322 , 64th Cong., 1st Sess. 5 (1916).

2s See supra notes 32,35 and accompanying text.

so See infra notes $96-111$ and accompanying text. 


\section{Some Consequences of More Lenient Taxation of Gifts}

The common objective of the gift and estate taxes is the taxation of the gratuitous transmission of wealth. ${ }^{40}$ This itself implies that consistency in the imposition of the taxes is desirable." ${ }^{41} \mathrm{Nev}$ ertheless, since 1916 Congress has continuously been content with less rigorous taxation of gifts. ${ }^{42}$ In that environment it is hardly surprising that taxpayers endeavored to subject gratuitous wealth transfers to the gift tax in lieu of the estate tax. Such efforts, and the congressional responses they have stimulated, account for much of the complexity that characterizes these taxes to this day. ${ }^{43}$

Recognizing the advantages to lifetime giving, an individual possessing wealth destined sooner or later to pass to a younger generation can, very generally, do one of two things. Most obviously, he can simply give away some of it now, thereby incurring the equally obvious disadvantage that control of the gift passes immediately to the succeeding generation. But he might also resort to more enterprising arrangements, trading on the fact that the line between lifetime gifts and transfers at death can be far from selfevident. Thus, an individual might create-through what in form are lifetime transfers and are typically (although not invariably) in trust-interests in his wealth which provide for eventual transmission to the ultimate beneficiaries while retaining strings that preserve use, control, or other benefits of ownership for himself in the interim. ${ }^{44}$ The general objective of such arrangements is to secure more lenient gift taxation of wealth transfers that in one sense or another do not become "complete" until the transferor's death."

so See Andrews, What's Fair About Death Taxes?, 26 NAT't TAX J. 465, 467 (1973); Wales, supra note 18, at 176-77.

41 See Wales, supra note 18, at 176.

13 See S. Surrey, W. Warren, P. McDaniel \& H. Gutman, supra note 5, at 4-13. The history through 1950 is recounted in Eisenstein, supra note 3, at 224-38.

ts See supra note 3.

4 See, e.g., May v. Heiner, 281 U.S. 238, $244-45$ (1930); Commissioner v. Northern Trust Co., 41 F.2d 732, 732-33 (7th Cir. 1930), aff'd sub nom. Burnet v. Northern Trust Co., 283 U.S. 782 (1931) (both holding that decedent's retention of an income interest for life in property transferred to a trust does not subject the trust corpus to the estate tax); cf. ALI STUDY, supra note 3, at 26-28 reprinted in 1976 STAFF MATERIALs, supra note 3, at 348-50 (discussing judicial construction of "gross estate" and congressional response); C. SHoup, supra note 3, at 26-28 (examining the mechanisms for policing incomplete transfers and gifts made in contemplation of death in I.R.C. $\$ \S 2035,2036,2038$ ); Eisenstein, supra note 3 , at 243 (estate tax base includes various types of inter-vivos transfers that are convenient will substitutes).

${ }^{4}$ See ALI STUDY, supra note 3, at 62-64 (discussing congressional responses to efforts to avoid estate tax by use of inter-vivos transfers). For a more detailed discussion of the statutory provisions that subject "incomplete" inter-vivos transfers to the estate tax, see 
The benefits of congressional tolerance of a comparatively lenient gift tax will ineluctably accrue to those willing to make outright gifts. Nevertheless, Congress has remained anxious to confine more lenient taxation to transfers that "truly" are lifetime gifts, and to forestall its extension to what are substitutes for, or in effect are, transfers at death. ${ }^{46}$ The resulting tension is manifest in a complex statutory scheme that deters various efforts to capitalize on advantageous taxation of gifts. Indeed, from its very inception, the estate tax has struggled with the treatment of outright gifts apparently motivated by the imminence of death (and of transfer taxation in any event)-so-called "deathbed gifts"-and with the treatment of lifetime gifts "with strings attached."

Section 202(b) of the Revenue Act of 1916, the statute that first enacted the modern estate tax, contained a rudimentary provision subjecting to tax both transfers "in contemplation of" a decedent's death and transfers "intended to take effect in possession or enjoyment at or after his death." evolved into what are now sections $2035-2038$ of the Code. ${ }^{48}$ Until 1976, deathbed gifts were dealt with by section 2035 (a) or its predecessors. ${ }^{4}$ The problem of incomplete lifetime transfers was and continues to be dealt with largely by sections 2036,2037 , and $2038 .{ }^{50}$

If successful, a deathbed gift could secure taxation of a wealth transfer at the explicitly lower marginal gift tax rates, applied to a tax base that (in contrast with the estate tax base) did not include the amount of the tax itself. For sixty years, therefore, one version or another of section 2035(a) endeavored to subject such gifts to taxation in a decedent's estate. ${ }^{51}$ There was no end of litigation..$^{52}$

infra notes $63-90$ and accompanying text.

18 See ALI STudy, supra note 3, at 62-64.

17 Revenue Act of 1916, Pub. L. No. 64-271, tit. II, $\S 202$ (b), 39 Stat. 756, $777-78$ (current version at I.R.C. $\$ \S 2035-2038$ (1982)).

4 I.R.C. $\$ \S 2035-2038$ (1982).

19 See I.R.C. § 2035(a) (1982) (including in the gross estates "the value of all property to the extent of any interest therein of which the decedent has at any time made a transfer . . . by trust or otherwise, in contemplation of his death"). For a discussion of the history of $\S 2035$ (a), see infra note 51 .

so I.R.C. $\$ \$ 2036-2038$ (1982).

s1 Section 2035(a) had a curious history, which brought it more or less full circle just as it became more or less superfluous. As enacted in 1916, the estate tax contained a rebuttable presumption-presumably inserted because no gift tax was enacted in 1916-that the transfer of a material part of the decedent's estate during the two years preceding his death was "in contemplation of death." Such transfers were required to be included in the decedent's estate for tax purposes. Revenue Act of 1916, Pub. L. No. 64-271, tit. II, § 202(b), 39 Stat. 756, 777-78; see also S. Surrey, W. WARREN, P. MCDANIEL \& H. GutMan, supra note 5, at 
Happily, section 2035(a) was consigned to history by the "adjusted taxable gifts" rule enacted in 1976 , which performs essentially the same function with respect to all taxable gifts as section 2035(a) used to fulfill when successfully applied to deathbed gifts. ${ }^{53}$ This consequence of the 1976 changes may have been overlooked in drafting the 1976 Act itself, but it was noticed shortly thereafter. ${ }^{54}$ In 1981, Congress largely repealed section 2035 (a). ${ }^{55}$

Two aspects of section 2035(a) are worth mentioning. First, a gift drawn into a decedent's estate by reason of that section was valued for estate tax purposes as of the decedent's death, instead of at its generally lower value on the date of the gift. ${ }^{.6}$ In contrast,

259-60 (discussing $\S 202$ (b) of the Revenue Act of 1916). When the gift tax that had been enacted by the Revenue Act of 1924, Pub. L. No. 68-176, tit. III, $\S \S 319-324$, 43 Stat. 253, 313-16, was repealed by the Revenue Act of 1926, Pub. L. No. 69-20, tit. XII, $\$ 1200,44$ Stat. 9, 126, the presumption was made irrebuttable. The Supreme Court, however; found that provision to be unconstitutional. Heiner v. Donnan, 285 U.S. 312, 331 (1932). In the Revenue Act of 1932, Pub. L. No. 72-154, tit. VI, § 803(a), 47 Stat. 169, 279, Congress therefore restored a rebuttable presumption that remained in effect for the ensuing 50 years. The principal subsequent change was an amendment made by the Revenue Act of 1950 providing that transfers more than three years before death were presumed not to be in contemplation of death. Eisenstein, supra note 3, at 250-51 (discussing Revenue Act of 1950); see also S. SuRrey, W. WARREN, P. McDaniet \& H. GuTman, supra note 5, at 260 (discussing Revenue Act of 1950). In the 1976 Act, however, Congress returned to a rule, similar to the one enacted in 1926, requiring that all gifts made within three years before death be included in a decedent's estate. Tax Reform Act of 1976, Pub. L. No. 94-455, tit. XX, $\S 2001$ (a)(5), 90 Stat. 1520, 1848 (amending I.R.C. § 2035(a)). Simultaneously, however, section 2035(a) was rendered largely superfluous by the "adjusted taxable gifts" rule of I.R.C. $\S 2001$ (b) (1982), discussed supra note 4, infra text at note 53.

${ }^{32}$ A brief review of this aspect of the estate tax, circa 1945, concludes with the observation that "[a]ny tax provision becomes unduly pathetic when it gears liability to such nonsense as the decedent's happy disposition, his practice of golfing once a week, or his entrenched habit of puttering about in his garden." Eisenstein, Are We Ready for Estate and Gift Tax Revision?, 23 TAXes 316, 319 (1945). Where the government was successful in invoking $\S 2035$ (a), and the transfer was restored to the decedent's estate, double taxation of the same transfer under both the gift and estate taxes was avoided by the allowance of a credit for the gift tax already paid against the estate tax subsequently levied on the transfer. See I.R.C. § 2012(a) (1982). Like § 2035(a) itself, see infra text at note 53, this provision was rendered superfluous by the "adjusted taxable gifts" rule. See I.R.C. § 2012(e) (1982).

s3 For a description of the operation of the adjusted taxable gifts rule, see supra note 4.

34 The estate and gift tax provisions were a somewhat hasty addition to the statute that ultimately became the 1976 Act. See S. Surrey, W. Warken, P. McDaniel, \& H. Gutman, supra note 5, at 9 (discussing the legislative history of the 1976 Act). This undoubtedly accounted for a number of flaws in the statute, including the apparently overlooked redundancy of $\S 2035$ (a) resulting from the "adjusted taxable gifts" rule of $\S 2001$ (b).

ss Economic Recovery Act of 1981, Pub. L. No. 97-34, tit. IV, § 424(a), 95 Stat. 172, 317 (codified at I.R.C. $\S 2035$ (d) (1982)). For the legislative history of this amendment, see S. REP. No. 144, 97th Cong., 1st Sess. 138-39 (1981) [hereinafter cited as 1981 SENATE REPORT], reprinted in 1981 U.S. CoDE CoNG. \& AD. NEws 105, 238-39; see also H.R. REP. No. 201, 97th Cong., 1st Sess. 186-87 (1981).

bB See 1981 SEnate Report, supra note 55, at 138, reprinted in 1981 U.S. Code Cong. 
the "adjusted taxable gifts" rule operates on the value of a lifetime gi.'t at the time it is actually made. ${ }^{57}$ After 1950 , however, section 2035(a) did not apply to gifts made more than three years before death, ${ }^{58}$ so it seems a reasonable conjecture that the increase in value taxed by reason of section 2035 (a), but not by the "adjusted taxable gifts" rule, would not have been breathtaking in the typical case. Second, section 2035(a) never did put deathbed gifts on exactly the same footing as transfers at death. It drew only the gift, not the gift tax, into the decedent's estate. Consequently, a gift included in a decedent's estate under section 2035(a) -in contrast with property actually owned by the decedent at death-was taxed on a tax-exclusive basis. The magnitude of this advantage alone could be substantial:;9 and it is one that, but for the advent in 1976 of section 2035 (c) ${ }^{60}$ would persist to this day. ${ }^{61}$

In contrast with section $2035(a)$, sections $2036-2038$ are still very much with us. ${ }^{62}$ Their continuing presence reflects an implicit congressional judgment, even after 1976, that, notwithstanding a lifetime transfer, retention of enumerated indicia of ownership should lead to inclusion of the wealth involved, valued as of the transferor's death, in the transferor's taxable estate. The operation of these rules can be triggered by the transferor's retention of a simple beneficial interest for life, of certain reversionary interests, or of powers over subsequent disposition of the principal or income

\& Ad. News 105, 238; S. Surrey, W. Warren, P. McDaniel \& H. Gutman, supra note 5, at 261-65.

37 See authorities cited supra, note 56.

ss For a description of the 1950 amendments to $\S 2035$ (a), see supra note 51.

so In one celebrated case a deathbed gift by a member of the DuPont family saved some $\$ 16$ million in estate taxes by removing some $\$ 21$ million in gift taxes payable from the decedent's estate. See In re Dupont, 41 Del. Ch. 300, 303-04, 194 A.2d 309, 311 (1963), noted in 112 U. PA. L. REv. 1083 (1964).

${ }^{60}$ I.R.C. § 2035(c) (1982).

61 See infra notes 103-07 and accompanying text.

62 I.R.C. $\$ \$ 2036-38$ (1982). Like the predecessor of $\S 2035$ (a), see supra note 51, these provisions had their genesis in the Revenue Act of 1916, Pub. L. No. 64-271, tit. II, $\$ 202$ (b), 39 Stat. 756, 777-78, and initially experienced rough going at the hands of the Supreme Court. In a series of decisions during the late 1920's and early 1930's, the original language of the Revenue Act of 1916 was progressively weakened, culminating in a decision that a lifetime transfer in trust, in which the decedent retained an income interest for the balance of her life, was not includable in the decedent's estate as a transfer "intended to take effect in possession or enjoyment at or after" the decedent's death. May v. Heiner, 281 U.S. 238, 243-45 (1930). Partly in response to these decisions, Congress, in the Revenue Act of 1932, Pub. L. No. 72-154, tit. VI, \& 803, 47 Stat. 169, 279-80, considerably strengthened the provisions dealing with "strings attached" gifts. While their subsequent history is somewhat tortuous, they still exist in much the same form they took as the result of the 1932 Act. For a fairly complete recitation of the history, see S. Surrey, W. Warren, P. McDaniel \& H. GutmaN, supra note 5, at 271-304. 
from the transferred property. ${ }^{63}$

The manner in which "strings attached" gifts could be used to secure more lenient gift taxation for what reasonably might be regarded as a testamentary transfer, and the way in which sections 2036-2038 respond to such efforts, can be illustrated by modifying the simple examples developed in Part I. Suppose that, though cognizant of the tax advantages of lifetime giving, $T$ is unwilling to part with his $\$ 100$ now. Although he would be happy to see the $\$ 100$ pass to his beneficiaries when he dies, he wants to retain for himself the income from the $\$ 100$ in the interim. $T$ consults his lawyer (not a tax expert) who informs him that these competing objectives might be achieved by creating a trust with a corpus of $\$ 60$-the anticipated value of $T$ 's estate after tax in Example $1^{64}$-reserving to $T$ the trust income for his life, and providing for the remainder to pass to T's designated beneficiaries at his death. ${ }^{65}$ The income interest for life, not having been transferred, is not taxed. ${ }^{66}$ The remainder, a presently transferred future interest that will be reduced to the beneficiaries' possession at T's death, is a taxable transfer. ${ }^{67}$

A complication arises from the fact that, even though the remainder is irrevocably created now, the assets will not pass to the recipients until some time in the future. To the recipients, the remainder is worth something less than $\$ 60$, because of the delay between its creation and the time it is expected to come into their possession. ${ }^{68}$ For tax purposes, its value must be discounted to reflect this delay. ${ }^{68}$

6s See I.R.C. $\$ \S 2036-2038$ (1982). For a discussion of the rationale for these provisions, see ALI Study, supra note 3, at 65-67; S. Surrey, W. WARren, P. McDaniel \& H. Gutman, supra note 5 , at $302-04$.

Sh See supra text following note 28.

${ }^{65}$ Such an arrangement is structurally identical to those upheld by the Supreme Court in May v. Heiner, 281 U.S. 238 (1930), and Burnet v. Northern Trust Co., 283 U.S. 782 (1931) (per curiam), aff'g Commissioner v. Northern Trust Co., 41 F.2d 732 (7th Cir. 1930).

os See I.R.C. $\$ \S 2511(a), 2512$ (a) (1982); Treas. Reg. § 25.2511-1(e) (1958) ("If a donor transfers by gift less than his entire interest in property, the gift tax is applicable to the interest transferred.").

${ }^{67}$ See Robinette v. Helvering, 318 U.S. 184, 187 (1943); Smith v. Shaughnessy, 318 U.S. 176, 181 (1943) (both holding that a currently transferred future interest is taxable as a gift at its discounted or present value).

68 See A. Alchian \& W. Allen, University Economics 204-09 (2d ed. 1967).

69 See Treas. Reg. $\S \S 25.2512-9(\mathrm{a})(1)(\mathrm{i})$ to $25.2512-9$ (e) (1970). Recently the Treasury has proposed revisions to these regulations, substituting a $10 \%$ discount rate for the $6 \%$ rate used in the 1970 regulations. See Revision of Actuarial Tables and Interest Factors, 48 Fed. Reg. 50,087, 50,108-11 (1983) (to be codified at 26 C.F.R. § 25.2512-5) (proposed Oct. $25,1983)$. The proposed regulations became effective on an interim basis on Dec. 1, 1983. Id. at 50,087 . 
To keep matters simple, assume that $T$ 's life expectancy and the appropriate discount rate to be used in valuing the remainder are such that $\$ 100$ to be paid on the anticipated date of T's death is worth $\$ 50$ today. $^{70}$ On that assumption, the present (or discounted) gift tax value of an indefeasible right to receive $\$ 60$ on the expected date of $T$ 's death is $\$ 30 .{ }^{71}$ Assuming no special estate tax provision, the tax consequences of this transfer would be as follows:

\section{Example 3}

$T$ has made a complete, taxable gift having a gift tax value of $\$ 30$. If taxed at $40 \%$, the tax would be $\$ 12$.

As far as T's beneficiaries are concerned, their receipt at T's death of this $\$ 60$ remainder is financially indistinguishable from their receipt of T's $\$ 60$ estate after tax in Example 1. But $T$ will have managed to secure taxation of the transfer as a gift instead of as part of his estate, reducing the transfer tax liability from $\$ 40$ (Example 1) to $\$ 12$ (Example 3). Of course, it is misleading to compare the nominal value of the $\$ 12$ gift tax in Example 3 with the $\$ 40$ estate tax paid in Example 1. The substitution of a gift tax payment for an estate tax payment has materially accelerated the

70 Assuming compound interest, the present (or discounted) value of a sum to be received in the future is determined by multiplying that sum by $1 /(1+i)^{n}$, where $n$ is the number of periods between the future date and the present, and $i$ is the interest rate per period. Conversely, the future value of a present sum is given by multiplying the present sum by $(1+i)^{n}$. See A. Alchian \& W. Allen, supra note 68, at 204-09; see also Appendix A, at 76.

The examples that follow all assume that $\$ 100$ to be received at the actuarially anticipated date of $T$ "s death has a value, discounted to the present date of the gift, of $\$ 50$; in other words that $(1+i)^{n}=2$, and that $1 /(1+i)^{n}=1 / 2$. Note that, once the discounting assumptions have been fixed, the value of $(1+i)^{n}$ is constant, so that, given our assumptions, the present value of a future sum is always one-half that sum, and the future value of a present sum is always twice that sum. See A. Alchian \& W. Allen, supra note 68, at 20409.

There are an infinite number of combinations of $i$ and $n$ that will lead to this outcome. Those wishing to put values on the variables may assume for present purposes that the discount rate is $10 \%$ per annum and that the number of years between the date of the gift and the anticipated date of T's death is 7.25.

Until recently, Treasury Regulations prescribed the use of a $6 \%$ discount rate in valuing a remainder of this sort for gift tax purposes. See Treas. Reg. $\S 25.2512-9$ (1970). Recently, the Treasury proposed revisions to the regulations incorporating a $10 \%$ discount rate. See supra note 69 . As a result, the examples in the text are more-or-less faithful to actual valuations.

${ }^{71}$ See authorities cited supra notes 68-69. Note, for comparison, that the $\$ 60$ estate after tax in Example 1, supra text following note 28, if discounted on the same assumptions to its present value as of the hypothesized date of the gift, is also worth $\$ 60 \times 1 / 2=\$ 30$. See supra note 70. 
timing of the payment. An adjustment must be made for this fact to arrive at a useful basis for comparison. On our discounting assumptions, the $\$ 12$ gift tax is the equivalent of a tax of $\$ 24$ to be paid on the anticipated date of $T$ 's death. ${ }^{72}$ Thus, by creating a remainder through lifetime transfer instead of waiting until death, $T$ could reduce from $\$ 40$ to $\$ 24$, or by $40 \%$, the effective tax liability associated with the transfer of $\$ 60$ at his death. This is exactly the result one would expect, on the basis of Examples 1 and 2, given the difference in the way we currently tax gifts and estates. ${ }^{73}$ What is more, although T's beneficiaries still receive $\$ 60$ at his death, the fact that the effective tax burden is lower leaves $T$ better off in the interim. ${ }^{74}$ The benefit of the tax advantage thus accrues to $T$.

Enter section 2036(a)(1). ${ }^{75}$ It requires that $T$ 's estate include "the value of all property ... of which the decedent has at any time made a transfer . . . under which he has retained for his life . . . the right to the income from" the property. ${ }^{76}$

\section{Example 4}

As applied to the transfer in Example 3, section 2036(a)(1) would draw the assets in which the remainder was created into T's estate for tax purposes. Their estate tax value would be $\$ 60$. To pay tax on this amount, however, $T$ 's estate should have on hand some additional, unburdened assets, in this instance $\$ 20 .{ }^{27}$ That amount, when added to the $\$ 60$ remainder,

72 See supra note 70; infra note 120.

73 See supra notes $29-30$ and accompanying text. That is, the gift tax associated with a $\$ 60$ gift is $\$ 24$, whereas the estate tax associated with a $\$ 60$ estate after tax is $\$ 40$. If the lifetime creation of the remainder is taxed as a gift, it too attracts the equivalent of a $\$ 24$ tax paid at death.

${ }^{74}$ On the assumptions we have been using, $T^{*}$ s right to the income from $\$ 100$ until the anticipated date of his death has a discounted value of $\$ 50$. See infra note 150; Appendix A, at 76. Where, as in Example 3, $T$ instead transfers $\$ 60$ in trust but retains an income interest in the $\$ 60$ for his life, the discounted value of the retained income interest is $\$ 30$. But, after his transfer of $\$ 60$ to the trust and payment of the $\$ 12$ gift tax resulting from the transfer, $T$ is left with $\$ 100-\$ 60-\$ 12=\$ 28$. The aggregate value of what $T$ is left with is the sum of (1) the discounted value of the income interest (\$30), plus (2) the cash (\$28), or $\$ 58$.

In present value, $T$ is $\$ 8$ better off. This advantage corresponds with the reduction in the effective transfer tax liability, valued as of $T$ s death ( $\$ 40$ in Example 1 as contrasted with $\$ 24$ in Example 3), of $\$ 16$. The value of $\$ 16$ discounted to the present from the anticipated date of T's death is $\$ 8$. The significance of the $\$ 28$ remaining in T's possession in Example 3 will be considered further, infra notes 138-40 and accompanying text.

${ }^{78}$ I.R.C. $\S 2036(a)(1)(1982)$.

ro Id.

${ }^{27}$ Although irrevocably transferred and thus not available to the decedent's personal 
would bring T's taxable estate to $\$ 80$. The "tentative" estate tax on $\$ 80$ (at $40 \%$ ) is $\$ 32$. To avoid double taxation of the same transfer under both the gift tax and the estate tax, the $\$ 12$ gift tax paid in Example 3 is subtracted from the $\$ 32$ "tentative" estate tax, leaving a net estate tax payable of $\$ 20 .^{78}$

Because of the intervention of section 2036(a)(1), $T$ and his estate now have incurred gift and estate taxes nominally amounting to $\$ 32$. As before, however, the $\$ 12$ gift tax, paid well in advance of T"s death, must be viewed as the equivalent of a $\$ 24$ tax paid at death. ${ }^{79}$ With this adjustment the total transfer taxes have a value at $T$ "s death of $\$ 44$-gift tax with a date-of-death value of $\$ 24$ plus estate tax of $\$ 20.80$ Thus, in connection with the ultimate transmission of $\$ 60$ at T's death, through the lifetime creation of the remainder depicted in Example 3, section 2036(a)(1) operates to impose a more burdensome combination of gift and estate taxes than if $T$ had never bothered to consult his lawyer in the first place. ${ }^{81}$ What is more, this additional tax is financed at the cost of $T$ 's well-being in the interim. ${ }^{82}$

In other words, section 2036(a)(1) actively deters the lifetime creation of remainders subject to retained life interests. Unlike sec-

representative, the $\$ 60$ date-of-death value of the remainder is part of $T$ "s taxable estate by reason of I.R.C. $\S 2036(a)(1)$ (1982). Thus, T's estate should have on hand cash equal to a tax on the sum of (1) the $\$ 60$ remainder, plus (2) the cash, reduced by (3) the $\$ 12$ gift tax already paid (the subtraction of which is called for by I.R.C. $\S 2001$ (b) (1982), see supra note 4 . At a $40 \%$ tax rate, the amount of cash, $x$, must equal $.4(60+x)-\$ 12$, so that $x=$ $\$ 20$. Note that the amount that must remain in T"s estate is less than the $\$ 28$ remaining in $T^{n}$ s possession after he created the remainder and paid the gift tax. See supra note 74.

78 I.R.C. $\$ 2001$ (b) (1982). For a description of the process of computing a tentative tax and the mechanism for taking account of taxable lifetime gifts in taxing a decedent's estate, see supra note 4.

79 See supra note 70; text accompanying note 72.

so The value of the total taxes, discounted to the date of the original gift, is $\$ 22$. The $\$ 20$ estate tax, discounted from T's death to the date of gift, has a value of $\$ 20 \times 1 / 2$ or $\$ 10$, see supra note 70 , to which must be added the gift tax of $\$ 12$.

"Compare supra text following note 28 (Example 1).

82 On the assumption that only the $\$ 60$ in which the remainder was created will be left by $T$ to pass to his beneficiaries, $T$ will be left with $\$ 28$ after creation of the remainder and payment of the tax, so that the total value of what $T$ retains-consisting of that $\$ 28$ plus the $\$ 30$ value of his income interest in the trust-is $\$ 58$. See supra note 74 .

But $T$ should provide for $\$ 20$ of the $\$ 28$ to pass to his estate, so that it will have the wherewithal to pay the estate tax on the remainder, see supra notes 77-78 and accompanying text, at least if this scheme ever were to be effectuated by design. The discounted value of the $\$ 20$ left to T"s estate is $\$ 10$, see supra note 70 , so that the value of what $T$ retains is $\$ 58-\$ 10=\$ 48 . T$ thus has $\$ 2$ less to consume than he would have had if he had done nothing-an amount that equals the discounted value of the increase in the transfer tax burden. See supra notes 80-81 and accompanying text. 
tion 2035(a), however, it was not made superfluous by the changes enacted in $1976 .{ }^{83}$ Without it, transfers with retained life interests would continue to be advantageous, even after the advent of a unified rate schedule and exemption, because of the continuing difference between the gift and estate tax bases. ${ }^{84}$

The object of this discussion is simply to illustrate the possibilities for manipulation of the still-existing difference in the taxation of gifts and estates, not to examine in detail the operation of the estate tax rules that Congress has interposed to deal with the problem. That said, I should add that the application of the gift and estate taxes to lifetime transfers subject to retained life interests is no more than a modest introduction to the complications created by sections 2036-2038. Transfers subject to these provisions can become enmeshed in a complex web of statutory and judge-made rules. ${ }^{85}$ As with transfers subject to retained life interests, some arrangments may be taxed under both the gift and estate taxes. ${ }^{86}$ In other instances, a "strings-attached" transfer will not be taxed at the time of its creation, but at some later date when the originally retained powers or interests are relinquished..$^{87}$ In still others, a transfer may fall within the ambit of more than one of these provisions. ${ }^{88}$ What is more, the law on when a lifetime transfer becomes sufficiently "complete" to be subject to the gift tax has developed largely in the absence of any statutory gift tax rules, leaving the courts to attempt, insofar as they have found it feasible, to minimize the extent to which wealth transfers would be subject to both the gift and estate taxes. ${ }^{89}$ Taken together, the

ss See supra notes 53-54 and accompanying text.

se See supra notes 21-28 and accompanying text. For a somewhat contrary view, see Isenbergh, Simplifying Retained Life Interests, Revocable Transfers, and the Marital Deduction, 51 U. CHI. L. REv. 1, 2-16 (1984):

os See S. Surrey, W. Warren, P. McDaniel \& H. Gutman, supra note 5, at 302-85; Dewind, supra note 3 , at $82-84$ (discussing the tax treatment of transfers covered by $\S \S 2036-2038$ ).

${ }^{86}$ See, e.g., Smith v. Shaughnessy, 318 U.S. 176, 179 (1943) (remainder taxed as a gift on creation even though conceded to be taxable as part of transferor's estate at death).

${ }^{87}$ See, e.g., Rasquin v. Humphreys, 308 U.S. 54, 56 (1939) (creation of a trust, under which the settlor reserved a power to redesignate remainder beneficiaries but retained no power to revest principal in himself, held not to be a completed gift); Estate of Sanford v. Commissioner, 308 U.S. 39, 46 (1939) (final relinquishment of a power similar to that retained in Rasquin $v$. Humphreys held to be taxable as a gift on relinquishment).

${ }^{83}$ See, e.g., Old Colony Trust Co. v. United States, 423 F.2d 601, 602 (1st Cir. 1970) (trust within the scope of both $\S 2036$ (a)(2) and $\S 2038(a)(1)$ ).

${ }^{80}$ See Estate of Sanford v. Commissioner, 308 U.S. 39, 46 (1939). The basic thrust of Estate of Sanford is that, if a gift is in a form such that it will be drawn into a decedent's estate by the operation of $\$ \S 2036-2038$, it will be considered "incomplete" when made and not subject to the gift tax. But see, e.g., Smith v. Shaughnessy, 318 U.S. 176, 179 (1943) 
rules are formidably complex. In general, the weight of the system tends to fall on the side of not taxing such arrangements at the time of their creation. In other words, lifetime wealth transfers subject to retained powers or interests are "hard to complete" for gift tax purposes, and are more likely to be exposed to transfer taxation at death. ${ }^{90}$

For present purposes the important point is that the machinery with which we police the use of "strings attached" lifetime transfers is a principal source, possibly the principal source, of complication in our transfer tax system. Since lifetime wealth transfers can so readily be deployed to achieve what are essentially testamentary objectives, such complications are an inevitable feature of a system that tolerates comparatively lenient taxation of lifetime gifts. ${ }^{91}$ Ridding the system of these problems has been a major focus of most studies of transfer tax revision. ${ }^{92}$

The degree of advantage enjoyed by lifetime gifts obviously was reduced by the revisions to the transfer tax rate and exemption structure enacted in $1976 .^{93}$ Less obviously, it was moderated further by the rate reductions enacted in $1981 .{ }^{.4}$ But to the extent that we continue to tax gifts more leniently than we do estates, that fact alone will (and should) influence the extent to which, as a matter of policy, lifetime gifts are made "difficult" or "easy" to complete for transfer tax purposes, and will affect the degree of

(remainder taxed as a gift on creation even though conceded to be taxable as part of transferor's estate at death).

90 See, e.g., Estate of Sanford v. Commissioner, 308 U.S. 39, 46 (1939) (transfer in trust not taxable as a gift where the transferor reserved the power to change the beneficiaries; it is subject to tax at the transferor's death); Treasury Proposals, supra note 3, at 354-55, reprinted in 1976 StAFF MATERIals, supra note 3, at 254-55 (a lifetime transfer over which the transferor retains sufficient control is taxed as a part of the transferor's estate at death).

91 Cf. Dewind, supra note 3, at 93 (observing that because the gift tax imposes so much lighter a burden than the estate tax it cannot serve as a substitute for estate taxation).

92 See, e.g., authorities cited supra note 3.

os See S. Surrey, W. Warren, P. McDaniel \& H. Gutman, supra note 5, at 267-71; Isenbergh, supra note 84 , at 6-12.

- See supra note 12 and accompanying text; Isenbergh, supra note 84, at 12-14. Achieving taxation of gifts consistent with the taxation of estates requires multiplying the nominal gift by $1 /(1-t)$ where $t$ is the nominal estate tax rate, expressed as a decimal fraction. As $t$ declines, so does the value of $1 /(1-t)$, thereby reducing the size of the required adjustment. The net effect is that the advantage conferred on lifetime giving by not making this adjustment is smaller at lower nominal rates. See infra notes 99, 168-70 and accompanying text; see also S. SuRrey, W. WARREN, P. McDaniel \& H. GutMan, supra note 5, at 269 ("as the tax rates themselves increase as the amount of the transfer increases, the benefit from the failure to gross-up increases accordingly"); Kurtz \& Surrey, supra note 3, at 1373 ("[b]ecause the [gift] tax rates themselves increase as the size of the transfers increase, the failure to include the tax in the base ... is of increasing advantage as the amount of the transferor's assets increases"). 
complication in the system. Conversely, achieving true neutrality in the taxation of lifetime transfers and transfers at death might allow the choice of rules to be made solely on grounds of administrability, and therefore holds out the possibility of substantial estate tax simplification. ${ }^{95}$ Accordingly, the balance of this article will assume true unification to be a desirable objective, and will consider how that objective best might be attained.

\section{Methods of Eliminating the Difference Between Gift and Estate Taxation}

If the existing difference between gift and estate taxation arises from failing to "tax the tax" on a lifetime gift, rectifying it requires restoring the gift tax paid to the transfer tax base. But simply taxing the $\$ 24$ of gift tax in Example 2 does not accomplish the desired objective; tax at $40 \%$ on the gift tax of $\$ 24$ yields additional tax of $\$ 9.60$, or total transfer taxes of $\$ 33.60$, still less than the $\$ 40$ estate tax in Example 1. If all transfers and all transfer taxes are to be included in the tax base, the additional tax of $\$ 9.60$ must also be taxed. This second increment of tax is $\$ 3.84$, bringing total taxes to $\$ 37.44$, once again short of $\$ 40$.

What ultimately is necessary is to find some additional amount which, when added to the $\$ 24$ gift tax and taxed together with the gift tax at $40 \%$, will yield tax equal to the additional amount. In Example 2, the required additional amount, of course, turns out to be the $\$ 16$ remaining after $T$ made the $\$ 60$ gift and paid $\$ 24$ in tax. If both that $\$ 16$ and the $\$ 24$ in gift tax were taxed,

95 See Isenbergh, supra note 84, at 12-16. A complete discussion of how those rules might look were the transfer taxes to be completely unified is beyond the scope of this paper. It is suggestive, however, that in 1969, when the Treasury proposed complete transfer tax unification, see infra text accompanying notes $96,98-102$, it also proposed a shift from a "hard-to-complete" to an "easy-to-complete" gift rule. TrEasury Proposals, supra note 3, at 361, reprinted in 1976 STAFF MAterials, supra note 3, at 261; see also C. Shoup, supra note 3 , at 25 (a completely integrated tax would eliminate or de-emphasize the elaborate policing provisions necessary in the present system); Kurtz \& Surrey, supra note 3, at 137576 (because under a unified system there is considerably less or no tax advantage to lifetime transfers, an "easy to complete" rule becomes possible, taxing lifetime transfers when created despite the retention of interests or rights in the property). Professor Surrey, the Assistant Secretary of the Treasury for Tax Policy at the time the Treasury Proposals were formulated, evidently has had second thoughts since 1969. See S. Surrey, W. Warren, P. MCDANIEL \& H. GuTMAN, supra note 5, at 441-42 (speculating that a more stringent "hardto-complete" rule than the one applied at present may be appropriate). The ALI Study adopted alternate recommendations on the "easy-to-complete" versus "hard-to-complete" question, depending on whether the dual tax system was preserved or a tax with a unified rate structure was substituted in its stead. See ALI STUDY, supra note 3, at 41-47, reprinted in 1976 Staff Materials, supra note 3, at 363-69. 
the total increment to the tax base would be $\$ 40$, attracting additional tax of $\$ 16$. Increasing the tax base by $\$ 40$ thus equalizes the outcomes in Examples 1 and 2.

When Congress was considering what ultimately became the transfer tax revisions of the 1976 Act, it had before it two major studies of the issues involved. The Treasury Department's Tax Reform Studies and Proposals (the Treasury Proposals), which recommended unification of the gift and estate taxes, had been prepared during the twilight of the Johnson Administration and published in early 1969.96 The American Law Institute's Federal Estate and Gift Taxation project (the ALI Study), which examined in detail; but made no final recommendation on, unification of the gift and estate tax rate and exemption structure, appeared at about the same time. ${ }^{97}$ These two studies took diverging approaches to rectifying the difference in the gift and estate tax bases under discussion here.

The Treasury Proposals explicitly addressed the issue. They proposed altering the computation of tax on a lifetime gift, at the time the gift was made, so that it would equal the tax associated with an identical private wealth transfer when made through a decedent's estate. ${ }^{98}$ Although not actually set out in the Treasury Proposals, the kind of adjustment the Treasury had in mind can readily be specified. For any given nominal tax rate, $t$, the adjustment consists of dividing by $(1-t)$ the gift tax value of a gift. ${ }^{90}$

- Treasury Proposats, supra note 3, at 329-409, reprinted in relevant part in 1976 Staff Materials, supra note 3, at 231-309.

${ }^{97}$ ALI STUdy, supra note 3, reprinted in part in 1976 StapF Materials, supra note 3, at 311-79. Even though much of the ALI Study was devoted to considering the substitution of a transfer tax with a unified rate schedule and exemption for the then existing dual estate and gift taxes, at various levels the ALI appears to have been internally divided over the advisability of such a change. On this pivotal issue no proposal was presented by the Reporters to the Institute itself, and no recommendation was adopted. See id. at 55-57, reprinted in 1976 STAFF Materials, supra note 3, at 377-79.

Although both the Treasury Proposals and the ALI Study were published before Congress completed work on the Tax Reform Act of 1969, Pub. L. No. 91-172, 83 Stat. 487, estate and gift tax revision did not find its way into the 1969 Act. The House Ways and Means Committee Report indicated that this omission was due to a shortage of time, and suggested that the subject would be taken up in the near future. H.R. REP. No. 413, pt. 1, 91st Cong., 1st Sess. 2 (1969), reprinted in 1969 U.S. Code Conc. \& AD. News 1645, 1646.

The relevant estate and gift tax recommendations of the Treasury Proposals and a portion of the ALI Study were reprinted, together with other materials concerning estate and gift tax revision, for use of the House Ways and Means Committee in early 1976. See 1976 Stafr Materials, supra note 3, at 231-309, 311-79.

98 Treasury Proposals, supra note 3 , at 355, 369, reprinted in 1976 Staff Materials, supra note 3 , at $255,269$.

"O Given a taxable estate $E$ and a tax rate $t$, the estate tax is $t E$ and the estate after tax 
The quotient is the "taxable" gift. In the context of Example 2-in which a $40 \%$ rate is applied to a $\$ 60$ gift $^{100}$ - the proper adjustment would be to divide the gift by $(1-.4)$, or .6 . As a result, $T$ 's nominal gift of $\$ 60$ is transformed into a "taxable" gift of $\$ 60 / .6$, or $\$ 100$. The tax base is thereby increased from $\$ 60$ to $\$ 100$, and the gift tax, at $40 \%$, from $\$ 24$ to $\$ 40$. These operations bring the tax imposed on a $\$ 60$ lifetime gift into line with the tax on a $\$ 100$ estate. This approach, which Congress declined to incorporate into the 1976 Act, ${ }^{101}$ generally is referred to as "grossing-up" the gift. ${ }^{102}$

The recommendations of the $A L I$ Study were substantially more modest. Indeed, as far as one can ascertain, the ALI Study, while cognizant of the difference between the gift and estate tax bases, ${ }^{103}$ elected not to recommend eliminating the difference, apparently out of concern for creating a disincentive to lifetime giving. ${ }^{104}$ Nonetheless, the Reporters were sensitive to the substantial tax savings that could be achieved by using deathbed gifts to forestall the imposition of estate tax on the gift tax that became payable by reason of the gift. ${ }^{108}$ In recognition of this possibility, the $A L I$ Study advocated restoring to a decedent's gross estate the tax on gifts made within two years before death. ${ }^{106}$ Congress adopted a

is $E-t E$, or $E(1-t)$. For an equivalent after-tax gift of $E(1-t)$, when taxed at rate $t$, also to attract tax of $t E$, it first must be divided by $(1-t)$. See, e.g., C. Shoup, supra note 3, at 16-17 (discussing formula for grossing-up the gift tax value of a gift).

${ }^{100}$ See supra text preceding note 29.

101 See H.R. REP. No. 1380, 94th Cong., 2d Sess. 11-15 (1976) [hereinafter cited as 1976 House ReporT], reprinted in 1976 U.S. Code Cong. \& AD. NEws 3356, 3365-69 (accompanying H.R. 14844, 94th Cong., 2d Sess. (1976), which was subsequently incorporated into the 1976 Act); H.R. REP. No. 1515, 94th Cong., 2d Sess. 607-09 (1976), reprinted in 1976 U.S. Code Cong. \& Ad. News 4118, 4246-48.

102 See, e.g., Treasury Proposals, supra note 3, at 355, 369, reprinted in 1976 Stafp Materials, supra note 3, at 255, 269; S. Surrey, W. Warren, P. McDaniel \& H. Gutman, supra note 5, at 269; Kurtz \& Surrey, supra note 3, at 1373.

${ }^{103}$ ALI STUDY, supra note 3, at 118-19.

104 Id. at 118-20. This issue is discussed further infra notes 113-19 and accompanying text.

${ }^{103}$ See ALI Study, supra note 3, at 44-45, reprinted in 1976 Staff Materials, supra note 3 , at 366-67. For a discussion of the then prevailing advantages of deathbed transfers, see supra note 50 and accompanying text.

${ }^{100}$ See ALI Study, supra note 3, at 44-45, 47, reprinted in 1976 Staff Materials, supra note 3, at 366-67, 369. Actually, the $A L I$ Study made two separate but related recommendations, a step dictated by the fact that alternative proposals were needed depending on whether a "dual" tax system was preserved or a system with a unified rate schedule and exemption was substituted in its place-a matter on which the $A L I$ Study took no position. See supra note 97 . The proposed restoration to the taxable estate of gift taxes with respect to gifts within two years before death was advanced in the context of a tax with a unified rate structure. In the context of a "dual" tax, the $A L I$ Study proposed to include in the decedent's estate gifts "in contemplation of" death, as under then existing law, and then to allow a refund of, or to abate any unsatisfied liability for, gift taxes resulting from the gift. 
similar rule when it enacted section $2035(\mathrm{c}),{ }^{107}$ which draws into the estate the gift taxes paid with respect to all gifts made within three years before death.

With respect to those lifetime transfers to which it applies, section 2035(c)-like the "gross-up" approach advocated by the Treasury-can operate to equalize the taxation of gifts and estates. Referring again to Example 2,08 suppose that, immediately after making the $\$ 60$ gift and paying $\$ 24$ in gift tax, $T$ died, and the remaining $\$ 16$ passed to and was taxed in his estate. Suppose also that section 2035(c) applied to include the $\$ 24$ gift tax in T's gross estate for tax purposes, even though only $\$ 16$ actually passed to his estate. T's taxable estate would be $\$ 40$, and the tax, at $40 \%$, would be $\$ 16$, entirely depleting the estate. ${ }^{109}$ In total, $\$ 60$ would have passed to $T$ 's beneficiaries, and $\$ 40$ would have been paid to the government, as in Example 1.110 Thus, like the "gross-up" approach, section 2035(c) appears to bring the taxation of a $\$ 60$ lifetime gift into line with taxation of an equivalent estate. ${ }^{111}$

In its existing form, however, section 2035(c) is more limited than the "gross-up" advocated in the Treasury Proposals; it applies only to transfers within three years before death. Even where it does apply, moreover, it differs from the Treasury Proposals in the matter of timing. The Treasury would have levied a tax-inclusive tax at the time of a gift; the existing system continues to levy

Refund or abatement would have had the effect of bringing the gift taxes back into the decedent's estate. $I d$. at 44.

${ }_{107}$ I.R.C. $\S 2035$ (c) (1982) (added to the Code by the Tax Reform Act of 1976, Pub. L. No. 94-455, tit. XX, § 2001(a)(5), 90 Stat. 1520, 1848-49). See 1976 House REPoRT, supra note 101, at 11-15, reprinted in 1976 U.S. Cone CoNG. \& AD. News 3356, 3365-69.

108 See supra text preceeding note 29.

109 Under the actual operation of the "adjusted taxable gifts" rule of I.R.C. \& 2001(b) (1982), discussed supra note 4, the result specified in the text would be achieved by a technically more elaborate route. A "tentative tax" would be computed on the sum of T"s "adjusted taxable gifts" (the $\$ 60$ gift in Example 2) plus his "taxable estate" (consisting of assets of $\$ 16$ plus $\$ 24$ by reason of I.R.C. $\$ 2035$ (c) (1982), or a total of $\$ 40$ ) so that the "tentative tax" would be $.4 \times \$ 100=\$ 40$, from which would be subtracted the $\$ 24$ of gift tax paid, leaving an estate tax actually payable of $\$ 16$.

110 See supra text following note 28.

112 Note, however, that I.R.C. $\S 2035$ (c) (1982) operates in this fashion only on the assumption that, after its application, the estate has sufficient assets to pay the tax. If, to change the assumptions in the text, $T$ had had the opportunity to expend for consumption the entire \$16 remaining in his possession after he made the lifetime gift and paid the resulting gift tax, the estate would have a tax liability of $\$ 9.60$ resulting from the inclusion of the $\$ 24$ gift tax under $\S 2035$ (c), but there would have been no cash in the estate to pay it. Thus, $\$ 2035$ (c) can only operate to unify the transfer tax base if $T^{p} s$ estate has other assets sufficient to pay the tax on whatever amount is included in his estate under $\S 2035$ (c), plus the tax on those other assets. See supra note 77. 
a tax-exclusive gift tax, relying on section 2035(c), where it applies, to tax the gift tax at the transferor's death. Putting aside the three-year limitation of existing law, however, it appears that both section 2035(c) and grossed-up taxation of gifts restore the same number of dollars to the transfer tax base. As a consequence, either approach might form the basis for unifying the gift and estate tax bases.

\section{Comparing the Methods of Unifying the Gift and Estate TAX BASES}

Given two different ways of achieving a unified gift and estate tax base, is there a principled basis for choosing between the two, assuming Congress should be disposed to legislate in this area? The choice entails at least two considerations: first, whether one method or the other achieves substantively preferable results; and second, whether one method or the other would be materially easier to comply with and administer. The object of this part of the article is to demonstrate that the approach advocated by the the Treasury in 1969 is superior to section 2035(c) in achieving neutrality in the taxation of comparable wealth transfers. The concluding section suggests how the scheme proposed by the Treasury in 1969 might be implemented simply.

The first of these conclusions is advanced in the face of a discernible reluctance to tax gifts in the same way that we tax estates, as the approach advocated in the 1969 Treasury Proposals would require. In part, this reluctance reflects a general apprehension about discouraging lifetime wealth transfers unduly. ${ }^{112}$ This apprehension is fortified by the perception that, when an individual transfers wealth by lifetime gift instead of waiting until death, the resulting acceleration of the transfer tax payment increases the real tax cost of making the transfer. ${ }^{113}$ Requiring also that gift

11 See 1976 House REPORT, supra note 101, at 11-15, reprinted in 1976 U.S. CoDE Cong. \& AD. News 3356, 3365-69.

11 See, e.g., ALI STUDY, supra note 3, at 119 (arguing that since a donor is deprived of a gift tax payment earlier than if he had transferred the wealth at death, he "should be compensated ... to some extent by an otherwise lower overall cost of making lifetime transfers"); Collie, Estate and Gift Tax Revision, 26 NAT'L TAX J. 441, 443 (1973) ("The lower gift tax rates also can be justified . . . by the fact that the gift tax is collected earlier than a corresponding estate tax ...."); cf. Alexander, Federal Estate and Gift Taxation: The Major Issues Presented in the American Law Institute Project, 22 TAx L. REv. 635, 645 (1967) ("a matter of personal judgment . . . whether lifetime giving should be encouraged by more favorable tax treatment or . . . discouraged ... through a unified transfer tax approach"). But see Kurtz \& Surrey, supra note 3, at 1390 ("The only way to provide for an equitable encouragement of gifts is to adopt a unified transfer tax system with 
taxes be computed in the same way as estate taxes, the argument proceeds, would render the increase in tax cost excessive. ${ }^{114}$

In some sense, this apprehension can be viewed as reflecting a desire to tax lifetime gifts preferentially. ${ }^{115}$ If, however, the objective is simply to avoid discrimination against lifetime giving, such concerns are misplaced. In financial terms, a tax paid now undeniably has a higher real cost than a tax of identical amount not payable until sometime in the future. But by the same token, a gift made now is of greater value to the recipient than a transfer of the same amount not made until some later date. A sound comparison of the two must take account of the fact that, in terms of financial value, the earlier gift is effectively larger. Thus, the higher real cost of the tax liability associated with an earlier gift, even when taxed on exactly the same basis as a later gift, simply reflects the transmission of more real value to the recipient.

Consider $T$, who (as we have been assuming) has $\$ 100$ now and expects to have that same $\$ 100$ at the anticipated date of his death (chosen arbitrarily so as to produce, in conjunction with an equally arbitrary discount rate, a $50 \%$ discount from the expected date of death to the present). ${ }^{116}$ Assume, contrary to existing law, that a transfer of $\$ 100$ would attract a tax of $\$ 40$, regardless of whether the transfer occurs now or at T's death, so that $\$ 60$ would pass to T's beneficiary in either event. If the transfer were made now, and the recipient invested the $\$ 60$ at the hypothesized interest rate, she would have $\$ 120$ at the actuarially predicted date of $T$ 's death. But if $T$ waited until death to transfer the $\$ 100, T$ 's beneficiary then would receive only $\$ 60$-half as much-after payment of the $\$ 40$ estate tax, a difference that is attributable to T's consumption of the income from $\$ 100$ in the interim. ${ }^{117}$ The fact

gross-up for lifetime transfers and then allow some percentage discount in the rate applicable to gifts as compared to death transfers.").

116 See, e.g., ALI Study, supra note 3, at 119; Collie, supra note 113, at 443-44.

11 Such a desire, however, is not invariably regarded as being incompatible with a unified transfer tax. See C. SHoup, supra note 3, at 128 (conferees generally favored a unified system but manifested some support for lower gift tax rates in the interest of inducing more lifetime giving); Kurtz \& Surrey, supra note 3, at 1390 (equitable encouragement of gifts requires adoption of a unified system with an attendant discount in the gift tax rates).

116 See supra note 70, where the terms of these assumptions are laid out.

117 The difference in what the beneficiary ends up with in the two cases is accounted for by the fact that, when $T$ waits until death before making the transfer, he retains, rather than transfers, the right to the income from $\$ 100$ from the present until the date of his death. The difference in $\operatorname{tax}$ is accounted for by the fact that value retained rather than transferred is not taxed. See supra note 66 and accompanying text. On our discounting assumptions, the right to receive the income from $\$ 100$ from the present until the anticipated date of $T$ 's death, if valued as of $T$ "s death, is $\$ 100$. If discounted to present value it is 
that a $\$ 40$ tax payment now is twice as costly as a $\$ 40$ tax payment made at $T$ 's death, at least on our discounting assumptions, ${ }^{118}$ simply mirrors the receipt by $T$ 's beneficiary of twice as much value if she receives $\$ 60$ now instead of $\$ 60$ at the time of T's death.

Conversely, the process of discounting implies that, expressed in nominal values, a gift made now will be smaller in amount than a financially equivalent transfer at death. Correspondingly, the tax imposed on a present gift should have a lower nominal value than the tax imposed on a financially equivalent transfer at death. Looking again to $T$ and his beneficiary for illustration, the equivalent of a $\$ 100$ tax-inclusive transfer now, which would attract a tax of $\$ 40$ and leave $\$ 60$ after tax for T's beneficiary, is a $\$ 200$ transfer on the anticipated date of T's death. ${ }^{119}$ A $\$ 200$ taxable estate would attract twice as much estate tax-\$80 at a $40 \%$ rate-leaving the recipient with $\$ 120$.

In other words, the mere fact that gift tax payments are made earlier than estate tax payments is not a sound basis for taxing gifts more leniently than estates. Comparisons involving values expressed consistently-either by reducing all transfers and tax payments, whenever made, to present value, or by extending them all to their value as of some future date-are more reliable as a guide to whether consistent taxation has been achieved. Similarly, a comparison of the operation of grossed-up taxation and taxation under section 2035(c) should focus consistently on present or future values. ${ }^{120}$

worth $\$ 50$. See supra note 70; infra note 150; see also Appendix A, at 76.

118 See supra note 70.

11 This amount would pass to T's estate if $T$, having decided not to make a gift now, not only preserved the $\$ 100$ principal for transmission at death, but also refrained in the interim from expending the income from the $\$ 100$. If $T$ simply invested the $\$ 100$ at the hypothesized rate of interest, he would have $\$ 200$ on the anticipated date of his death. See supra note 70 . The increase in what the beneficiary receives is offset by a reduction in what $T$ consumes.

${ }^{120}$ The analysis in the text implicitly assumes that it is appropriate to use identical rates to discount the value of future accessions to wealth and future tax liabilities. Given the imponderables involved in selecting "the right" discount rate, that assumption a priori seems to be as reasonable as any other.

Professor Isenbergh points out, however, that in practice this assumption may not be realistic. Future tax liabilities, he maintains, should be reduced to present value using a higher discount rate, reflecting greater uncertainty. Isenbergh, supra note 84, at 11-12; Isenbergh, Further Notes on Transfer Tax Rates, 51 U. ChI. L. Rev. 91, 93-94 (1984).

What his point appears to boil down to is that, ineluctable though both may be, death is more inevitable than taxes. There may be merit to that, although its resolution (even in this limited context) is in some respects a matter of speculation. In any event, it seems to me appropriate to confront the issue in its purest form, before proceeding to possible refinements based on informed judgment. 


\section{A. Transfers with Retained Life Interests}

A comparison of the application of section 2035(c) and grossed-up taxation to transfers subject to retained life interests requires us to revisit Example 3. ${ }^{121}$ There, $T$ created a remainder interest in $\$ 60$ through a lifetime transfer, the remainder was valued at $\$ 30$ for gift tax purposes, and the gift tax, at a $40 \%$ rate, was $\$ 12$-the equivalent of a $\$ 24$ tax to be paid at the anticipated date of $T$ 's death.

These events left $T$ with $\$ 28$-his original $\$ 100$ minus $\$ 60$ in which the remainder was created minus gift tax of $\$ 12$. Assuming $T$ did not expend those assets for consumption in the interim, they would pass to his estate at death. ${ }^{122}$ In the absence of a provision like section 2036(a)(1), ${ }^{123}$ and assuming for the moment that section $2035(c){ }^{124}$ does not apply, $T$ 's taxable estate would be limited to the $\$ 28$ in his possession at his death, the estate tax on which, at $40 \%$, would be $\$ 11.20{ }^{125}$ Assuming $T$ had died on the actuarially predicted date, $T$ and his estate would have paid total transfer taxes whose value, as of T's death, amounted to $\$ 35.20$-advantageous by comparison with the $\$ 40$ estate tax paid in Example $1 .^{126}$

If, however, section 2035(c) were applied without regard to whether the gift was made during the three years preceding T's death, $T$ 's taxable estate would include not only the $\$ 28$ but also the $\$ 12$ gift tax paid on creation of the remainder, as depicted in Example $3 .^{127}$ Bearing in mind that, in nominal terms, section

12x See supra notes 71-72 and accompanying text.

122 The assumption that the income from the $\$ 28$ is expended and that the principal is preserved for transmission is admittedly arbitrary. It is consistent, however, with the original premise that $T$ wished to expend income but was willing to preserve principal. The arbitrary nature of the assumption is addressed at a later point in the analysis, see infra notes 153-56 and accompanying text.

123 I.R.C. $\$ 2036(\mathrm{a})(1)$ (1982), discussed supra notes 75-84 and accompanying text, would bring the trust corpus into T's estate at its date-of-death value of $\$ 60$.

124 I.R.C. § 2035(c) (1982), discussed supra notes 107-10 and accompanying text.

125 As a technical matter, this result would be reached via the "adjusted taxable gifts" rule of I.R.C. $\$ 2001$ (b) (1982), discussed supra note 4. The "adjusted taxable gifts" rule requires computation of a "tentative tax" on the sum of the gift tax value of the lifetime gift in Example 3, $\$ 30$, plus the $\$ 28$ taxable estate, or a total of $\$ 58$. Tax on this amount at $40 \%$ is $\$ 23.20$, from which there is subtracted the gift of $\$ 12$ already paid in Example 3 .

${ }^{128}$ See supra text following note 28 . Here, the $\$ 12$ gift tax has a date-of-death value of $\$ 24$, see supra note 72 and accompanying text, which, when added to estate tax of $\$ 11.20$, yields total taxes with a date-of-death value of $\$ 35.20$. The total taxes have a value discounted to the date of the gift of $\$ 17.60$. See supra note 70 .

127 In its existing form, I.R.C. $\$ 2035$ (c) (1982) is limited in its application to the tax on gifts made within three years before death. Note that $\$ 2035$ (c) brings the gift tax, but not the lifetime gift, into T's taxable estate. In contrast, I.R.C. $\$ 2036$ (a)(1) (1982), illustrated in Example 4, brings the lifetime gift (at its date-of-death value), but not the tax, into T's 
2035(c) "unifies" the gift and estate tax bases, ${ }^{128}$ we may test how well it accomplishes that objective, and renders unnecessary rules like that of section 2036(a)(1), by assuming for purposes of Example 5 that no special estate tax provision other than section 2035(c) applies.

\section{Example 5}

T's taxable estate now is $\$ 40$-assets of $\$ 28$ included in the estate plus the gift tax of $\$ 12$ drawn into the estate by section 2035 (c) - the tax on which, at $40 \%$, is $\$ 16$. T's estate after tax is $\$ 12$-assets of $\$ 28$ minus estate tax of $\$ 16 .^{128}$

$T$ and his estate now have paid total transfer taxes having a nominal (or undiscounted) value of \$28-the gift tax of $\$ 12$ (in Example 3) plus the estate tax of $\$ 16$ (in Example 5). But, as we have noted, the values of the taxes must be adjusted to take account of the fact that the $\$ 12$ gift tax is the equivalent of a $\$ 24$ tax at T's death. ${ }^{130}$ As the result of this adjustment, the date-of-death value of the total gift and estate taxes rises to $\$ 40$. Hence, the simple operation of restoring the gift tax paid to T's taxable estate brings the value of the total taxes into line with the $\$ 40$ estate tax actually paid in Example 1. ${ }^{131}$

This outcome suggests that section 2035(c), if applied generally to the gift tax in respect of all lifetime transfers subject to retained life interests, would rectify the consequence of the difference between the gift and estate tax bases, and thereby would eliminate any remaining tax advantage to the lifetime creation of remainders of the sort depicted in Example 3. So understood, and as thus amended, section 2035(c) might well justify repeal of section 2036(a)(1). . $^{132}$

Before drawing that inference, however, we should examine the alternative of taxing such transfers when made in a manner consistent with the taxation of estates, rather than equalizing the treatment at T's death. To do so we must modify Example 3 by "grossing-up" the gift tax value of the lifetime creation of the

estate.

${ }^{128}$ See supra notes 103-07 and accompanying text.

${ }^{128}$ Once again, this result is arrived at as a technical matter by way of the "adjusted taxable gifts" rule of I.R.C. § 2001 (b) (1982), discussed supra note 4.

130 See supra text accompanying note 72.

131 See supra text following note 28; Isenbergh, supra note 84, at 14-16. The significance of the $\$ 12$ remaining in T's estate is examined infra notes 143-56 and accompanying text.

${ }^{192}$ See Isenbergh, supra note 84 at 14-16 (proposing repeal of $\S 2036(a)(1)$ ). 
remainder. The adjustment appropriate to a $40 \%$ tax rate calls for multiplying the nominal gift by $1 / .6$, or $1.667 .{ }^{133}$ The gift tax value of the remainder created in Example 3 is $\$ 30$, the discounted value of the right to receive $\$ 60$ on the anticipated date of T's death. ${ }^{134}$

\section{Example 6}

Although T's remainder is valued at $\$ 30$, it now has an adjusted (or "grossed-up") value for gift tax purposes of $\$ 30 \times 1.667$, or $\$ 50$. When taxed at $40 \%$, the gift tax now is $\$ 20$.

On our discounting assumptions, the $\$ 50$ "grossed-up" gift tax value of the remainder is simply the discounted equivalent of T's $\$ 100$ taxable estate in Example $1 .{ }^{130}$ The $\$ 20$ gift tax is the equivalent of the $\$ 40$ tax actually imposed on that estate.

Example 6, however, is simply the counterpart to Example 3, modified to depict grossed-up taxation of the creation of the remainder. Still missing from the analysis is a counterpart to Example 5, tracing matters through to their culmination at $T$ 's death. For the events in Example 6, like those in Example 3, did not entirely deplete $T$ 's wealth. In Example 3, $T$ was left with $\$ 28$. Here he is left with $\$ 20{ }^{136}$

Assume, to be consistent with Example 5, that the $\$ 20$ remaining principal passed to T's estate at his death. ${ }^{137}$ As with section 2035(c), the operation of the gross-up approach may be tested on the hypothesis that section 2036(a)(1) is unnecessary. ${ }^{138}$ Moreover, since grossed-up taxation operates to tax the gift tax as well, in this instance it is unnecessary to include the $\$ 20$ gift tax in T's estate. Therefore, section 2035(c) also may be hypothesized to be unnecessary. Only the $\$ 20$ actually in T's possession at his death need be included in his estate.

\section{Example 7}

The tax on T's $\$ 20$ estate at $40 \%$ is now $\$ 8$. T's estate after tax is $\$ 20-\$ 8$, or $\$ 12 .{ }^{139}$

The undiscounted sum of the gift and estate tax liabilities in

19s See supra notes $99-100$ and accompanying text.

136 See supra note 71 and accompanying text.

1ss See supra note 70 and accompanying text.

136 After creation of a remainder in $\$ 60$ and payment of a $\$ 20$ gift tax, $T$ has $(\$ 100-\$ 60)-\$ 20=\$ 20$.

${ }^{187}$ See supra note 122 and accompanying text.

1ss See supra text following note 128.

1ss See supra note 129. 
Examples 6 and 7, which exemplify the operation of grossed-up taxation, is \$28, just as it was in Examples 3 and 5, which together exemplify the operation of section 2035 (c). ${ }^{140}$ But the timing of the mix of payments differs. Under the gross-up approach the gift tax is $\$ 20$ (rather than $\$ 12$ ), offset by the fact that the estate tax is $\$ 8$ (rather than $\$ 16$ ).

This timing change alters the financial value of the taxes. The date-of-death value of the specific combination of gift and estate taxes produced by Examples 3 and 5 was $\$ 40 .{ }^{141}$ The different mix of payments in Examples 6 and 7 produces taxes with a total dateof-death value of $\$ 48,{ }^{142}$ exceeding by $\$ 8$ the $\$ 40$ estate tax actually paid in Example 1. The outcome under section 2035(c), as illustrated by Examples 3 and 5, still seems more consistent with simple estate taxation.

Nevertheless, grossed-up taxation is demonstrably preferable. On further analysis, the simple case of Example 1, in which $T$ left $\$ 100$ to be taxed in his estate, is financially different from either pair of examples in which, by lifetime transfer, $T$ created a remainder in assets equal to the anticipated after-tax value of his estate. The difference turns on T's payment of the gift tax. Although perhaps not immediately apparent, and although dependent on the subsequent course of events, that payment can function to create an incremental wealth transfer by $T$.

In Example 1, T's designated beneficiaries received $\$ 60$ on T's death, after payment of $\$ 40$ of estate tax. When $T$ created a remainder by lifetime gift-regardless of whether that transfer was taxed as it would be under existing law (Example 3) or through grossed-up taxation (Example 6) - the remainder alone was due to provide $\$ 60$ to $T$ 's beneficiaries at his death. ${ }^{143}$ Both examples 5 and 7 then illustrate that, at T's death, additional value passed from $T$ "s estate to his beneficiaries.

In Example 7, T's estate was left with $\$ 20 .{ }^{144}$ After payment of $\$ 8$ in estate tax, $T$ 's beneficiaries received (assuming $T$ so directed) $\$ 12$, in addition to the $\$ 60$ remainder. Thus, in lieu of the simple $\$ 60$ estate after tax in Example 1, the date-of-death value of the total after-tax wealth transfer produced by Examples 6 and 7 adds

140 This result is exactly what one would expect. See supra text accompanying notes 109-11.

141 See supra text accompanying notes 130-31.

${ }^{142}$ The date-of-death value of the $\$ 20$ gift tax is $\$ 40$, see supra note 70 , to which must be added the $\$ 8$ estate tax, yielding $\$ 48$.

14 See supra text following note 71.

14 See supra text accompanying notes 137-39. 
up to $\$ 72$. As we have already noted, the date-of-death value of the total gift and estate taxes is $\$ 48$.

In Example 5, $\$ 28$ was left to T's estate. For tax purposes, however, section 2035(c) also brought into the estate the $\$ 12$ gift tax, with the result that the estate tax, at $40 \%$, was $\$ 16 .{ }^{145}$ Once again T's estate after tax was $\$ 12$. Thus, the pattern of Examples 3 and 5, like that of Examples 6 and 7, also operates to transmit a total of $\$ 72$ to T's designated beneficiaries. In Examples 3 and 5, however, the date-of-death value of the total transfer taxes is only $\$ 40.148$

Assuming a $40 \%$ tax rate, taxes having a date-of-death value of $\$ 48$ are consistent with aggregate pre-tax wealth transfers having a date-of-death value of $\$ 120-\$ 20$ more than the $\$ 100$ taxable estate in Example 1. The resulting after-tax wealth transfer should be $\$ 120$ minus $\$ 48$, or $\$ 72$. These values correspond precisely with the date-of-death value of the sum of what T's beneficiaries receive from, and what the government takes by taxation of, a combination of the remainder created by lifetime gift (Example 6) and T's estate at death (Example 7).

By comparison, one way of looking at Examples 3 and 5 is that the effective tax rate on the aggregate wealth transferred to $T$ 's beneficiaries has declined. The date-of-death value of the total taxes (\$40), expressed as a percentage of the date-of-death value of the sum of the transfers plus taxes ( $\$ 72$ plus $\$ 40$, or $\$ 112),{ }^{147}$ yields an effective, tax-inclusive transfer tax rate of only $35.7 \%$, even though the nominal tax rate is $40 \%$. Under grossed-up taxation, the effective rate remains equal to the $40 \%$ nominal rate.

Another way of viewing the events depicted in Examples 3 and 5 is that, given a $40 \%$ tax rate, the payment of transfer taxes having a date-of-death value of $\$ 40$ is consistent with T's having made pre-tax wealth transfers with a date-of-death value of $\$ 100$. However, the $\$ 72$ that actually passed to $T$ 's beneficiaries is consistent with $T$ 's having made pre-tax wealth transfers with a date-of-death value of $\$ 120 .{ }^{148}$ Under this view, the pre-tax equivalent of $\$ 20$ passed untaxed to T's beneficiaries by reason of the method of taxation illustrated in Examples 3 and 5. Appendix A suggests that this latter interpretation is the more useful. ${ }^{148}$

\footnotetext{
145 See supra text accompanying notes 127-29.

146 See supra text accompanying notes 130-31.

147 See supra notes 29-30 and accompanying text.

14 See supra notes 29-30 and accompanying text; text following note 146.

149 See infra Appendix A, at 79-80, 83-84.
} 
One might inquire how $T$ managed to make pre-tax wealth transfers totalling $\$ 120$ when he commenced this exercise with only $\$ 100$. The answer begins with the recognition that a pre-tax transfer of $\$ 100$ on the actuarially expected date of T's death has a value, on the discounting assumptions we have been using, of only $\$ 50$ on the date of the lifetime gift. The difference, or $\$ 50$, is the discounted value of T's right to the income from $\$ 100$ in the interim. ${ }^{150}$ The combination of these two interests entirely accounts for the value of having $\$ 100$ now. When viewed from the date of $T$ 's death, instead of from the present, the income interest and the remainder interest each has a value of $\$ 100$. Their aggregate future value-the future value of having $\$ 100$ now-adds up to $\$ 200 .^{151}$

If we tax lifetime transfers and transfers at death identically, the government should (to use our simplifying assumption about rates) take $40 \%$ of the tax-inclusive value of whatever $T$ transfers whenever and however he transfers it. ${ }^{152}$ It should take nothing of

150 If, as an analytical matter, the value of having $\$ 100$ today may be conceived of as consisting of the present value of the right to dispose of that $\$ 100$ at some future date plus the present value of the right to receive income from $\$ 100$ in the interim, and if the present value of the right to dispose of the $\$ 100$ in the future is $[\$ 100]\left[1 /(1+i)^{n}\right]$, see supra note 70 , then

$$
\begin{aligned}
& \$ 100=P V_{I}+[\$ 100]\left[1 /(1+i)^{n}\right], \\
& P V_{I}=\$ 100-[\$ 100]\left[1 /(1+i)^{n}\right], \text { and } \\
& P V_{I}+[\$ 100]\left[1-1 /(1+i)^{n}\right],
\end{aligned}
$$

where $P V_{I}$ is the present value of the income interest. See Appendix A, at 76.

On the discounting assumptions we are using, the present value of $\$ 100$ to be received at T's anticipated death is $\$ 100(1 / 2)=\$ 50$. See supra note 70 and accompanying text. The present value of the right to the income in the interim, therefore, is $\$ 100(1-1 / 2)=\$ 50$.

181 See supra text accompanying note 119.

${ }^{182}$ This proposition, especially in light of the considerations set out supra, text accompanying notes 114-19, implies that, whatever the merits of the competing technical arguments, the decision in United States v. O'Malley, 383 U.S. 627, 634 (1966) (income accumulated and added to the corpus of an irrevocable trust treated as having been "transferred" by the grantor/trustee and therefore includable in his gross estate), was soundly conceived, at least under the existing system.

The proposition might be regarded as a refinement of what Professor Gutman has advanced as a "normative principle" of wealth transfer taxation, which would tax all wealth transfers at a predetermined rate. See Gutman, supra note 6, at 1216-18. The refinement is in the demonstration (rather than the assertion) that, to achieve consistency, the gift tax base must be fixed on a consistent basis with the estate tax base at the time the gift is made.

It is important to recognize, however, that the fundamental objective is consistency. Altering the gift tax base to conform it to the estate tax base, in contrast, is simply a matter of convention. At least in theory, consistency could as readily be achieved by eliminating the transfer tax from the estate tax base. For a given array of nominal transfer tax rates the choice between one method or the other of achieving consistency is essentially a choice between one set of effective rates and another.

But then, under either approach, effective rates could be fixed at whatever level is con- 
what $T$ chooses to retain. Thus, when $T$ elected to live off the income from $\$ 100$ and to leave $\$ 100$ at his death, as depicted in Example 1, in effect he chose to retain half the value-the "income" half-attributable to having $\$ 100$ in hand at the time he made that decision. The remaining $\$ 100$ of principal, ultimately due to be transferred, was also ultimately due to be taxed. What is more, since $T$ elected to consume the "income half," the burden of the tax was destined to fall on the "remainder" half of the value attributable to having $\$ 100$ now. That "remainder" half has a present value of $\$ 50$, and a value at the time it is expected to pass to $T$ 's estate of $\$ 100$, leaving $\$ 60$ (after tax at $40 \%$ ) for $T$ 's beneficiaries.

When, instead, $T$ chose to create the remainder by lifetime transfer and to pay the transfer tax himself, he paved the way for shifting the incidence of the tax. Instead of the tax being paid by $T$ 's estate, thereby depleting the wealth that passed to T's beneficiaries after estate tax, its discounted equivalent was paid as gift tax by $T$. That payment, in contrast with the creation of the remainder, actually depleted $T$ 's wealth, thereby reducing the value of the income $T$ could expect to receive during the balance of his life. ${ }^{158}$

By substituting a gift tax payment for an equivalent estate tax payment, of course, $T$ only potentially shifted the burden of the transfer tax to himself. He still retained the option of taking subsequent steps to offset his payment of the gift tax. Assuming that the lifetime creation of the remainder had attracted gift tax of $\$ 20$ under the gross-up approach of Example 6, $T$ could have compensated for his payment of the tax by thereafter consuming the $\$ 20$ of principal that remained in his possession. ${ }^{154}$ But when $T$ elected instead to restrict future consumption to his remaining income, he completed an incremental transfer of wealth. He actually sacrificed, in favor of his beneficiaries, the right to receive the income

sidered to be appropriate by the simple expedient of readjusting the nominal rates.

${ }^{283}$ Of itself, the voluntary creation of the remainder does not require $T$ to forego any value attributable to the income from his wealth. But payment of the gift tax associated with the creation of the remainder actually depletes $T$ 's income-producing principal.

186 The assets remaining in $T^{P}$ s possession after creation of the remainder and payment of the tax, on the assumption that creation of the remainder was taxed as illustrated in Example 6, would have been \$20. See supra note 136 and accompanying text. If $T$ had elected to expend the entire $\$ 20$ for consumption, no assets would have passed to $T$ 's estate at his death and no further transfer tax would have been due. $C$ f. supra text accompanying notes $137-39$. As a result, only the $\$ 60$ remainder would pass to $T$ "s beneficiaries at his death, and only a $\$ 20$ gift tax-the equivalent of a $\$ 40$ tax paid at death, see supra note 70 -would have been paid. The net effect would be the same as it was in Example 1. 
from the $\$ 20$ paid as tax for the duration of his expected remaining life. That sacrifice accounts for the additional wealth transfer that materialized in Example 7.

One can readily specify the value of the income interest $T$ gave up by his election. On the assumptions used throughout this discussion, that interest has a discounted value of $\$ 10$ and a value as of T's death of $\$ 20 .^{155}$ The latter corresponds exactly with the incremental pre-tax wealth transfer that appeared as $T$ 's taxable estate in Example 7, at least when T's creation of the remainder was taxed under the gross-up approach as illustrated in Example 6.

Much the same thing occurs under section 2035(c), as illustrated by Examples 3 and 5. In that instance, however, the government foregoes collecting a part of the tax until $T$ dies. As it happens; this deferral exactly offsets the additional tax that otherwise would be imposed on the additional wealth transfer through $T$ 's estate. ${ }^{156}$ The implication of these examples is that, under the

185 The present value of the foregone right to the income from $\$ 20$ for $T$ 's life is $\$ 20(1-1 / 2)=\$ 10$. See supra note 150 . The value at $T$ 's death of something worth $\$ 10$ now is $\$ 10 \times 2=\$ 20$. See supra note 70 .

From a different perspective, $T$, before taking any action, possessed $\$ 100$, the income interest in which for $T^{p} s$ life has a discounted value of $\$ 50$ and a date-of-death value of $\$ 100$. After creation of the remainder and payment of $\$ 20$ in gift tax, $T$ was left with an income interest in a $\$ 60$ trust plus $\$ 20$ in cash. If $T$ elected to consume only the income from the $\$ 20$ plus the income from the trust, $T$ would be left with an income interest in $\$ 80$ having a discounted value of $\$ 40$ and a date-of-death value of $\$ 80$.

${ }^{158}$ The value of the deferral is the value of an income interest for $T^{\mathrm{T}} \mathrm{s}$ expected remaining life in the portion of the tax that is deferred. See supra note 150, and Appendix A, at 85. That value, as it happens, exactly offsets the tax that would be imposed on a wealth transfer equal in value to an income interest in the incremental tax that would have been imposed through "grossed-up" taxation of the transfer in the first place. See Appendix A, at 84-85.

Note that, as in the case of "grossed-up" taxation of the remainder, $T$ may compensate for his having paid the gift tax by subsequently expending principal for consumption. See supra note 154. If taxed under $\S 2035(c)$, however, $T$, by subsequent consumption of all remaining principal, could more than offset the value of the income interest foregone through payment of the tax.

After payment of the $\$ 12$ gift tax, $T$ would be left with the right to income from the $\$ 60$ in trust plus $\$ 28$ in cash. See supra text following note 121 . These items have an aggregate discounted value of $\$ 58$. See supra notes 74,82 . The only constraint on $T$ 's consumption is that he ought to conserve sufficient cash to allow his estate to satisfy the tax liability attracted by inclusion in his estate of (1) the $\$ 12$ gift tax (under $\S 2035(\mathrm{c})$ ), plus (2) the cash left to the estate. Thus, $T$ should leave $\$ 8$ to his estate. See supra note 77 and accompanying text.

If $T$ does so, $T$ still will be able to expend for consumption an income interest in $\$ 68$ - the income from the trust plus the income from the $\$ 8$ that he leaves to his estate-which has a discounted value of $\$ 34$, see supra note 150 , plus $\$ 20(\$ 28-\$ 8)$ in cash, or total value of $\$ 54$. Thus, even though T's beneficiaries receive $\$ 60$ at $T$ 's death, as they did in Example 1, T is better off in the interim. In other words, § 2035(c) effectively would permit $T$ to provide for transmission to his beneficiaries, at lower tax cost, of the same $\$ 60$ as in Example 1, leaving $T$ to consume more in the interim. See supra note 74 and accompa- 
gross-up approach to taxation of lifetime gifts, the incremental wealth transfer created by T's foregoing the income on the gift tax payment is itself taxed (on a tax-inclusive basis) at the $40 \%$ transfer tax rate, accounting for the additional $\$ 8$ of estate tax. By contrast, taxing the gift as under current law and postponing until death the inclusion of the gift tax in the transfer tax base-thereby deferring a portion of the tax on the lifetime gift-exempts the incremental transfer from tax. ${ }^{157}$

These inferences are not the fortuitous result of the numerical assumptions adopted in the examples. Appendix A makes the same comparisons in general terms, and demonstrates that the results hold for other tax rates and discounting assumptions. Regardless of the value of the assets in which a remainder is created by lifetime transfer, where creation of the remainder operates to transfer more than the anticipated after-tax value of the transferor's estate, the gross-up approach taxes the incremental transfer. ${ }^{168}$ Section 2035 (c), in contrast, yields taxes with a combined value that usually equals, and never exceeds, the estate tax that would have been paid in the absence of the lifetime transfer. ${ }^{150}$ In short, when ap-

nying text.

${ }_{167}$ Compare this to a similar, and increasingly visible, phenomenon under the income tax: the tax deferral resulting from the allowance of a current deduction for the cost of making an income-producing investment operates to exempt from tax the income subsequently derived from that investment. For a discussion of this phenomenon, see, for example, Andrews, A Consumption-Type or Cash Flow Personal Income Tax, 87 Harv. L. Rzv. 1113, 1127 (1974); Surrey, The Tax Reform Act of 1969 - Tax Deferral and Tax Shelters, 12 B. C. Indus. \& Com. L. REv. 307, 313 (1971).

158 The algebraic exposition in Appendix $A$ indicates that $T$ can create a remainder interest in assets in an amount that exceeds his estate after tax in Example 1 (i.e., $\$ 60$ ). Under grossed-up gift taxation his ability to do so is limited only by the fact that the sum of the assets in which the remainder is created, plus the resulting gift tax, may not exceed $\$ 100$. On the assumptions we have been using, $T$ could create a remainder interest in at most $\$ 75$. See Appendix A, at 80-81. The gift tax value of the remainder would be $\$ 37.50$. See supra note 70 . If grossed-up for a $40 \%$ tax rate, the "taxable" gift of $\$ 37.50 \times 1.667=\$ 62.50$, see supra note 99 and accompanying text, the tax on which is $\$ 25$. Creation of the remainder and payment of tax thus entirely account for T's $\$ 100$. Note that the tax (\$25) is $40 \%$ of the aggregate tax and transfer ( $\$ 37.50+\$ 25=\$ 62.50$ ).

168 Appendix A demonstrates that, under $\S 2035$ (c), $T$ also may create a remainder in as much as $\$ 75$. Cf. supra note 158 . Under that regime, $T$ 's ability to create a remainder in more than $\$ 60$ is limited by the need for $T$ to retain sufficient free cash so that his estate can pay the tax on the sum of (1) the gift tax drawn into his estate under section 2035(c), plus (2) the cash retained to pay the tax. See Appendix A, at 86-87; see also supra note 77.

The gift tax value of a remainder in the maximum of $\$ 75$ would again be $\$ 37.50$, and the gift tax, at $40 \%$, would be $\$ 15$, leaving $T$, after creation of the remainder and payment of the gift tax, with $\$ 100-\$ 75-\$ 15=\$ 10$. Inclusion in $T$ 's estate of that $\$ 10$ together with the gift tax of $\$ 15$ would create a taxable estate of $\$ 25$, the tax on which would be $\$ 10$. See supra note 129. Note that the date-of-death value of the total transfer taxes is, as in Examples 3 and 5, $\$ 40$, consisting of the date-of-death value of the $\$ 15$ gift tax (\$30) plus 
plied to lifetime transfers with retained life interests, the approach advocated by the Treasury in 1969 would tax lifetime gifts consistently with existing taxation of transfers at death. Section 2035(c) does not.

\section{B. Outright Gifts}

As applied to lifetime transfers with retained life interests, the consequence of the choice between grossed-up gift taxation and generalizing section 2035(c), once identified, is fairly dramatic. The implications of the choice for outright gifts are more readily discernible if slightly less striking.

Once again, the difference can be illustrated by example. Only one assumption need be changed. Since by hypothesis $T$ is willing to make an outright gift, we now may assume that he is willing to forego in favor of his beneficiaries the entire value of the $\$ 100$ in his possession. Under grossed-up taxation, $T$ could give his beneficiaries only $\$ 60$.

\section{Example 8}

The nominal value of $T$ 's gift is $\$ 60$. The adjustment called for under the gross-up approach would require it to be multiplied by $1.667,{ }^{180}$ yielding a "taxable" gift of $\$ 100$, the tax on which, at $40 \%$, would be $\$ 40$. The combined gift and gift tax entirely absorb $T$ 's $\$ 100$.

By contrast, under section 2035(c), no adjustment would be required at the time the $\$ 60$ gift is made. As in Example 2, the gift tax would be $\$ 24$. After making the gift and paying the tax, $T$ would be left with $\$ 16$. On our revised assumption, however, $T$ now should be willing to sequester all value attributable to this $\$ 16$ and apply it to further transfers to his beneficiaries. In other words, we may assume that $T$ will accumulate the income from this $\$ 16$ while he is alive and will leave the principal plus accumulated income to his beneficiaries when he dies.

The $\$ 16$ will, under our assumptions, be worth $\$ 32$ at T's death, ${ }^{161}$ and that amount will be included in T's taxable estate.

the estate tax (\$10). See supra note 70.

The date-of-death value of the total taxes will amount to $\$ 40$ for the creation of a lifetime remainder in any amount between $\$ 60$ and $\$ 75$. See Appendix A, at 87-88. Thus, regardless of the actual size of the transfer, the tax imposed remains consistent with the transmission of a $\$ 100$ estate.

${ }^{180}$ See supra notes $99-100$ and accompanying text.

${ }^{181}$ See supra note 70. 
Under section 2035(c), T"s estate for tax purposes also will include the $\$ 24$ gift tax paid. ${ }^{162}$

\section{Example 9}

$T$ now has a taxable estate of $\$ 56$. The estate tax, at $40 \%$, is $\$ 22.40$. T's estate after tax is $\$ 32-\$ 22.40$, or $\$ 9.60 .{ }^{163}$

In this instance $T$ is able to make wealth transfers having an aggregate present value of $\$ 64.80$, consisting of the sum of the $\$ 60$ lifetime gift, plus the discounted value of $T$ 's $\$ 9.60$ estate after tax, or $\$ 4.80 .^{164}$ Under a consistent scheme of tax-inclusive wealthtransfer taxation, the tax associated with an after-tax wealth transfer of $\$ 64.80$ should be $\$ 43.20 .^{185}$ But the taxes actually paid have a combined present value of only $\$ 35.20$ - the sum of $\$ 24$ of gift tax plus an estate tax of $\$ 22.40$, the present value of which is $\$ 11.20$.

One interpretation of these results is that an after-tax wealth transfer of $\$ 64.80$ is consistent, conceptually, with T's having made pre-tax wealth transfers of $\$ 108$, the tax on which ought to be $\$ 43.20{ }^{168}$ By contrast, the total tax actually paid is consistent with $T$ 's having made pre-tax wealth transfers of only $\$ 88$ (the tax on which would be $\$ 35.20$ ). On this view, the pre-tax equivalent of $\$ 20$ again was transmitted untaxed. A second interpretation is that, despite the $40 \%$ nominal rate, the effective tax rate on T's aggregate transfers is only $35.2 \%(\$ 35.20 / \$ 100)$. In either event, the present value of the sum of what $T$ 's beneficiaries receive in Examples 2 and 9 is $\$ 4.80$ more, and what the government takes in tax is $\$ 4.80$ less, than their respective shares in Example 8.

Once again, the approach proposed by the Treasury in 1969 operates unremittingly to subject wealth transfers of comparable size to consistent taxation. In contrast, section 2035(c) confers a continuing advantage on the use of lifetime gifts. It does not truly equalize the gift and estate tax bases, and it does not actually unify the taxes themselves.

${ }^{102}$ Assuming, once again, that $\S 2035$ (c) were to be applied without regard to the threeyear limitation of existing law. See supra note 127.

${ }^{16 s}$ See supra note 129.

166 See supra note 70.

1es That is, to be taxed on a tax-inclusive basis, the $\$ 64.80$ after-tax transfer would have to be grossed-up for a $40 \%$ rate, yielding an adjusted gift of $\$ 64.80 \times 1.6667=\$ 108$. See supra notes $99-100$ and accompanying text. The tax on $\$ 108$ at $40 \%$ would be $\$ 43.20$.

168 See supra note 165. 


\section{Practicability of the Gross-up Approach}

What remains to be determined is whether the Treasury approach is practicable. Section 2035(c) appears to create little difficulty in administration. At death, the decedent's personal representative simply must ascertain the amount of gift taxes paid with respect to transfers during the three preceeding years, and add that to whatever else is includable in the decedent's estate. Extending this rule to include the tax on all prior taxable gifts would present little additional difficulty. The application of the post-1976 unified rate schedule to the cumulative total of taxable gifts plus the decedent's estate already requires the personal representative to ascertain the amount of the decedent's "adjusted taxable gifts," defined to include post-1976 taxable transfers whether or not tax was actually required to be paid. ${ }^{\mathbf{1 6 7}}$ Acquisition of this information, typically from gift tax returns, necessarily would carry with it the amount of gift taxes actually paid by the decedent, thereby furnishing all the data needed to comply with section 2035(c).

Implementing a scheme of grossed-up taxation of lifetime gifts when made would appear to be somewhat more complicated, at least in a system involving graduated transfer tax rates. Indeed, the Treasury Proposals were not, at least on the question of mechanics, overly specific:

In addition to eliminating the dual rate base, the unified transfer tax would further equate lifetime and deathtime transfers by providing rules for computing the tax on lifetime transfers so that, in effect, the tax is paid out of the property transferred, as is the case with transfers at death. Thus, the proposal provides for computation of the tax on lifetime transfers by valuing the gift ("grossing-up" the gift) so as to include the amount of the tax within the amount of the gift upon which the tax is computed. A simplified table would be available to compute the grossed-up transfer, so that taxpayers would not be burdened by complex calculations. ${ }^{168}$

The difficulty with grossed-up taxation-perhaps accounting for the vagueness and the slightly defensive reference to "complex calculations"-is that, as we have already seen, the required adjustment to the gift varies with the nominal tax rate. This may be

${ }^{167}$ See I.R.C. $\S \S 2001(b), 2503(a)$-(b) (1982), discussed supra note 4. The limitation to post-1976 taxable gifts reflects the prospective operation of this provision of the 1976 Act.

${ }^{168}$ Treasury Proposals, supra note 3, at 355, reprinted in 1976 Staff Materials, supra note 3 , at 255 . 
illustrated by reconsidering algebraically a contemplated wealth transfer of a pre-tax amount $E$. If taxed at rate $t$ in a decedent's estate, the tax would be $t E$ and the estate after tax would be $E-t E$, or $E(1-t)$. A comparable transfer by lifetime gift would start with the net private transfer of $E(1-t)$, also to be taxed at rate $t$. To arrive at a tax liability of $t E$, as with taxation in an estate, the net private transfer must be divided by $(1-t){ }^{169}$ When the tax rate $t$ changes, as it will in a graduated tax system, the value of $(1-t)$ also will change. ${ }^{170}$ This alteration as a function of nominal transfer tax rates is one principal source of possibly "complex calculations."

A second complication is that the points at which successive alterations in the gross-up adjustment occur do not correspond with the nominal graduation points on the estate tax rate table. This second difficulty can be illustrated by considering a simplified set of estate tax rates that taxes the first $\$ 100$ of taxable estate at $20 \%$ and taxes transfers in excess of $\$ 100$ at $40 \%$. A $\$ 50$ transfer taxed at $20 \%$ in an estate would attract a tax of $\$ 10$, leaving $\$ 40$ after tax. A $\$ 40$ lifetime gift, also to be taxed at $20 \%$, would be multiplied by $1 /(1-.2)$, or 1.25 , yielding a "grossed-up" taxable gift of $\$ 50$, the tax on which, at $20 \%$, would also be $\$ 10$. If taxed at the $40 \%$ rate, a $\$ 50$ transfer at death would incur tax of $\$ 20$, leaving $\$ 30$ after tax; and the corresponding $\$ 30$ gift would (as we have repeatedly seen) be multiplied by 1.667 , again yielding a grossedup tax base of $\$ 50$ and now attracting a gift tax of $\$ 20$.

Suppose, however, that having made no prior taxable transfers, an individual makes a lifetime gift of $\$ 90$. The transfer is less than $\$ 100$, and apparently should be adjusted for a $20 \%$ tax rate by multiplying it by 1.25. But that operation gives rise to a grossed-up, "taxable" gift of $\$ 90 \times 1.25$, or $\$ 112.50$, thereby carrying the gift into the $40 \%$ bracket in which a different adjustment, multiplication by 1.667 , is called for. It is evident that the point of graduation in our simplified set of estate tax rates- $\$ 100$-assumes that the tax base to which the rates will be applied is, like the estate tax, tax-inclusive. The graduation point takes into account both the value of the private wealth transfer and the tax to be imposed on the transfer. Since, in contrast, the gift tax is computed by applying graduated rates to net private transfers, excluding the tax, the corresponding point of graduation-and the place at which the gross-up adjustment changes-falls elsewhere. Some-

169 See supra note 99.

170 See supra note 94; C. Shoup, supra note 3, at 16-17. 
how, the gift tax brackets must implicitly take the amount of the transfer tax into account in determining when the "real" point of graduation, determined by reference to the tax-inclusive estate tax rate schedule, has been reached.

In the simple example under consideration, that point occurs at $\$ 80$. Multiplication of the first $\$ 80$ of the $\$ 90$ gift by 1.25 yields a "taxable" gift of $\$ 100$ and a gift tax of $\$ 20$. The sum of the actual gift plus the gift tax now equals $\$ 100$. In terms of the tax-inclusive estate tax rate schedule, the next marginal bracket has been reached. The remaining $\$ 10$ gift is taxed at $40 \%$, after having been multiplied by 1.667, resulting in additional gift tax of $\$ 10 \times 1.667 \times .4$, or $\$ 6.67$.

The $\$ 90$ gift attracts total tax of $\$ 26.67$. In other words, the total pre-tax wealth transfer is $\$ 116.67 .{ }^{171}$ That amount, if taxed in the transferor's estate under the hypothesized set of estate tax rates, would also attract $\$ 26.67$ in tax. ${ }^{172}$ The after-tax transfer again would be $\$ 90$.

These two problems, however, point to a simple solution. While much of the discussion about unification of the transfer taxes contemplates "grossing-up" gifts for tax purposes, ${ }^{173}$ the simple fact is that a tax is always the product of a base and a rate. It is equally feasible to achieve consistency in taxing lifetime gifts by grossing-up the (tax-inclusive) estate tax rates. Doing so would create a nominally different-but in reality identical-set of gift tax rates which then could be applied to lifetime gifts without the need for any mechanical adjustment to the amount of the gift. What is more, the brackets on the transformed table of tax-exclusive gift tax rates could be fixed so as to ensure that the graduations in the rates occurred at those values of net private transfer corresponding to the graduation points on the tax-inclusive estate tax rate table.

In terms of our simple example-with the addition of an intermediate $30 \%$ bracket to fill out the illustration-the estate tax rate table and corresponding gift tax rate table would be as follows:

131 See supra notes 29-30 and accompanying text.

172 The first $\$ 100$ of the transfer would attract a tax, at $20 \%$, of $\$ 20$, while the $\$ 16.67$ balance of the transfer would attract a tax, at $40 \%$, of $\$ 6.67$.

17s See, e.g., Treasury Proposals, supra note 3, at 369, reprinted in 1976 Stapp Materials, supra note 3, at 269; C. Shoup, supra note 3, at 16-17. 


\section{ESTATE TAX}

TOTAL OF ADJUSTED TAXABLE

GIFTS, GIFT TAXES PAID,

AND TAXABLE ESTATE

TentaTive TAX ${ }^{174}$

0 to $\$ 100$

$20 \%$ of the total

$\$ 101$ to $\$ 200$

$\$ 20$ plus $30 \%$ of the total in excess of $\$ 100$

More than $\$ 200$

$\$ 50$ plus $40 \%$ of the total in excess of $\$ 200$

\section{GIFT TAX}

TOTAL OF ADJUSTED

TAXABLE GIFTS

0 to $\$ 80$

$\$ 81$ to $\$ 150$

More than $\$ 150$

\section{Tentative Tax}

$25 \%$ of the adjusted taxable gifts

$\$ 20$ plus $43 \%$ of the adjusted taxable gifts in excess of $\$ 80$ $\$ 50$ plus $67 \%$ of the adjusted taxable gifts in excess of $\$ 150$

A test of the operation of these tables can be carried out by comparing the tax imposed on an estate of $\$ 500$ with the gift tax imposed on a taxable gift that corresponds with the resulting estate after tax. Applying the rates set out in the Estate Tax table, the tax on a $\$ 500$ estate is $\$ 170$, leaving an estate after tax of $\$ 330 .{ }^{176}$ Under the Gift Tax table, the tax associated with a $\$ 330$ taxable gift is also $\$ 170 .{ }^{176}$ Identical tax liabilities would be attracted for any combination of lifetime gifts and transfers at death in between.

Appendix B contains both an algebraic derivation of the brackets on a transformed gift tax rate schedule, and a gift tax rate schedule corresponding with the existing unified rate schedule as it will look when the rate reductions prescribed by the 1981 Act are fully phased in. ${ }^{177}$

${ }^{174}$ As under existing law, see I.R.C. \& 2001(b) (1982), discussed supra note 4, the sum of the taxes paid on prior lifetime transfers would be subtracted from the "tentative tax" to arrive at the estate tax actually due.

176 Under the Estate Tax table, tax on the first $\$ 200$ would be $\$ 50$, and tax on the remaining $\$ 300$, at $40 \%$, would be $\$ 120$, yielding a total tax of $\$ 170$.

178 Under the Gift Tax table, tax on the first $\$ 150$ would be $\$ 50$, and tax on the remaining $\$ 180$, at $67 \%$, would be $\$ 120$, yielding a total tax of $\$ 170$.

${ }^{177}$ See supra note 12 for a discussion of the rates instituted by the 1981 Act. 
Once it is recognized that a transformed rate schedule can be devised that automatically taxes lifetime gifts on a grossed-up basis, the remaining mechanics are fairly simple. In computing the place at which the decedent's taxable estate falls on the graduated estate tax rate table, the executor need only ascertain the total of the decedent's taxable lifetime gifts (computation of which is required by existing law) plus the gift taxes paid (computation of which would be needed to comply with section 2035(c)) and add the sum of these items to whatever else is included in the decedent's estate. In reality, then, implementation of a fully unified transfer tax based on grossed-up taxation of lifetime gifts would be no more complicated than applying a generalized version of section 2035(c).

There does exist one final complication in the taxation of lifetime gifts consistently with the taxation of estates that cannot be remedied simply in any graduated system of transfer taxation. It stems from the fact that while present and future transfers may be set equal to one another by the process of discounting, the points of graduation on a rate table are fixed in nominal amounts. Consequently, where tax rates are graduated, a single table of rates cannot achieve complete consistency in taxing transfers that, although of identical present value, are made at different times and therefore have different nominal values. ${ }^{178}$

This phenomenon can be observed using the simple rate tables set out in the text above. Suppose that $T$ has $\$ 100$ now, and that this $\$ 100$, if allowed to accumulate interest, is expected to be worth $\$ 200$ as of the actuarially expected date of T's death. If it were left to accumulate and ultimately were taxed in T"s estate, the $\$ 200$ transfer would attract estate tax, given the rates fixed by the Estate Tax table, of $\$ 50$, leaving $\$ 150$ for T's beneficiaries. The present value of the tax and transfer, on the discounting assumptions used throughout this article, ${ }^{179}$ would be $\$ 25$ and $\$ 75$, respectively. If, instead, $T$ were willing to part with his $\$ 100$ now, he could make a gift of $\$ 80$. The gift tax would be $\$ 20$ and the sum of the gift plus the tax would be $\$ 100$. The tax associated with a current transfer is $\$ 5$ less than the present value of the tax associated with an equivalent transfer at death. Consequently, the value of the aftertax transfer is $\$ 5$ more.

In both instances the transfers have identical pre-tax present values. Moreover, the Gift and Estate Tax tables above have been

\footnotetext{
17 See supra notes 115-19 and accompanying text.

179 See supra note 70.
} 
fashioned so as to achieve consistent taxation of lifetime transfers and transfers at death. But the use of a lifetime gift has operated to attract tax to a transfer having a lower nominal value ( $\$ 100$ rather than $\$ 200$ ) and the tax rates are graduated in nominal terms. Consequently, a greater portion of the lifetime gift is taxed in a lower transfer tax bracket. This "bracket effect" is not, so far as I can tell, easily remedied if it is remediable at all. In any event, the advantage it confers under existing transfer tax rates is not more than approximately $\$ 400,000 .{ }^{180}$ The costs in complexity necessary to eliminate this final obstacle to perfect consistency are probably not worth whatever might be gained.

\section{CoNCLUSTON}

Two points emerge from this analysis. First, with one qualification, neutrality in the taxation of gratuitous wealth transfers by gift and at death can be achieved through "grossed-up" taxation of gifts. The rule currently embodied in section 2035(c) does not accomplish that objective. Second, no significant complexity need be involved in implementing a system of grossed-up taxation. What is more, it is likely that substantial gains in simplification of the gift and estate taxes would be made possible if we were to tax lifetime gifts and transfers at death in a fashion that is consistent. ${ }^{181}$ Altogether, enactment of a system of grossed-up gift taxation would be a welcome revision to our wealth transfer taxes. 


\section{APPENDIX A}

Considered below are various ways in which an individual, $T$, whose expected remaining life is $n$ years, might dispose of wealth $E$ to private beneficiaries. T's options include present transfers and transfers at death. Where $T$ is comparing options that involve present transfers with those involving transfers at death, values will be placed on a consistent footing by reducing future transactions to present value or extending present transactions to future value.

Given a discount rate $i$ and assuming periodic compounding for $n$ years, the value of $X$ dollars with compound interest at some future date is

$$
F V_{X}=X(1+i)^{n} \text {. }
$$

Similarly, the discounted (or present) value of the right to receive $X$ dollars $n$ years in the future-that is, the present value of a remainder interest in $X$ to be received in $n$ years-is

$$
P V_{X}=\frac{X}{(1+i)^{n}}
$$

It is assumed that $X$ may be invested at $i$ so as to earn interest annually of $i X$. The present value of a remainder in $X$ to be received after $n$ years, plus the present value of the right to the income from $X$ during the intervening $n$ years, when added together, equal $X$. Thus

and

$$
X=P V_{i X}+\frac{X}{(1+i)^{n}},
$$

$$
P V_{i X}=X \quad 1-\frac{1}{(1+i)^{n}}
$$

Since for any given discount rate $(i)$ and number of years $(n)$ the expression $(1+i)^{n}$ is constant, in the balance of this Appendix $D=(1+i)^{n}$ and

$$
\begin{aligned}
& F V_{X}=X D, \\
& P V_{X}=\frac{X}{D},
\end{aligned}
$$

and

$$
P V_{i X}=X\left(1-\frac{1}{D}\right)
$$

Finally, for simplicity of exposition, it is assumed the tax is imposed on all private wealth transfers without exclusion at a nominal rate $t$.

One of T's options is to live off the income from $E$ during life, leaving - $E$ at death. That option (Case 1 ) will be considered first.

Under one alternative (Case 2), $T$ will be assumed to make a present transfer (for example, in trust) of some portion of his assets, reserving an income interest for his life, remainder passing to designated beneficiaries. The retained income interest is not a taxable transfer. The value of the 
remainder is equal to the assets transferred, discounted to present value ovar T's expected remaining life. The creation of the remainder is a taxable transfer and will be taxed at rate $t$. In Case 2 the transferred remainder will be taxed in the manner proposed by the Treasury in 1969, by transforming the nominal transfer tax rate $(t)$ as necessary to achieve taxation of lifetime gifts, when made, in a manner consistent with the taxation of estates. Since the lifetime gift of the remainder is taxed when made there will be no need to tax it again in T's estate. Consequently, I.R.C. $\S 2036(a)(1)$ is assumed to have been repealed. Since the effect of taxing the gift consistently with the way it would be taxed at death is to tax both the lifetime transfer and the tax on the transfer-that is, in effect to tax the gift on a tax-inclusive basis at rate $t$-the gift tax also will be excluded from $T$ 's estate. Only the excess of $T$ 's original wealth $(E)$ over the sum of the assets in which $T$ created the remainder plus the amount of the gift tax paid will be taxed in T's estate.

In Case 2 it will be assumed initially that $T$ creates a remainder in assets equal to the anticipated value of his estate after tax in Case 1. Since it will appear that, by making the lifetime gift, $T$ in fact may increase the amount of after-tax wealth passing to his beneficiaries, the maximum amount that $T$ may transfer, subject to a retained life interest, will be described. Finally it will be shown that observations concerning the special case in which $T$ made a lifetime transfer equal to the originally anticipated after-tax value of his estate in Case 1 hold regardless of the magnitude of the lifetime transfer.

In . Case 3, as in Case 2, $T$ will be assumed to make a present transfer of a remainder, subject to a retained income interest for life. The remainder will be valued as it was in Case 2, but will be taxed as it would under current law by imposing tax at the nominal transfer tax rate $(t)$. Since, as in Case 2, the remainder will have been taxed when created, the repeal of section 2036(a)(1) again will be assumed and the assets in which the remainder was created will be excluded from $T$ 's estate. Since, however, the effect of taxing the lifetime gift as under current law is to forego taxing the gift tax (as contrasted with the gift itself), the gift tax paid will be included in T's estate at death. Thus, while the assets in T's estate will consist of the excess of $T$ "s original wealth $(E)$ over the sum of the assets in which $T$ created the remainder plus the amount of the gift tax paid, T's taxable estate will include the amount of those assets plus the gift tax.

As in Case 2, it initially will be assumed that $T$ creates a remainder in assets equal to the anticipated value of his estate after tax in Case 1. The relationships between the outcomes in Cases 2 and 3, and their relationship to the outcome in Case 1, will be described. Then it will be shown that in Case 2, as in Case 3, creating a remainder subject to an income interest for life allows $T$ (if he so desires) to make an additional transfer to his beneficiaries, and that the maximum amount by which $T$ can increase the transfer (while retaining a life interest) is the same in both cases. Finally, it will be shown that the relationships between the 
results in Cases 2 and 3 that appear in the special instance in which $T$ created a remainder in assets equal to his anticipated estate after tax in Case 1 hold regardless of the amount in which $T$ creates a remainder by lifetime transfer.

\section{Case 1: Taxation in T's Estate}

If $T$ lives off the income from $E$ for life, his estate will equal

$E$,

the estate tax will be

$$
t E,
$$

and the amount passing to $T$ 's beneficiaries after tax will be $E-t E$, or

$$
E(1-t) \text {. }
$$

The present value of the right to the income from $E$ for $T$ 's life equals (from 3 )

$$
P V_{i E}=E\left(1-\frac{1}{D}\right)
$$

The present value of the estate tax equals (from 2,5 )

$$
\frac{t E}{D}
$$

and the value of the estate after tax, similarly discounted (from 2,6), equals

$$
\frac{E}{D}(1-t)
$$

The sum of the present values of $T$ 's life interest in the income (7), the anticipated estate tax (5a), and the anticipated estate after tax (6a), is $E$.

Finally, the estate tax liability, $t E$, expressed as a percentage not of the taxable estate $(E)$ but of the estate after tax $(E-t E)$-in other words, as a percentage of the net transfer-is

$$
\frac{t E}{E(1-t)}=\frac{t}{(1-t)} \text {. }
$$

This is the "grossed-up" tax rate corresponding to a nominal transfer tax rate $t$, that is, it is the rate at which a net (tax-exclusive) transfer of $E(1-t)$ must be taxed so as to yield tax equal to the tax at rate $t$ on a gross (tax-inclusive) transfer of $E$.

\section{Case 2: Lifetime Transfer Taxed on a Grossed-Up Basis}

In Case 2, $T$ initially makes a current transfer of assets equal to his anticipated estate after tax in Case 1 , or $E(1-t)(6)$, reserving an income interest in the assets for his life, and irrevocably vesting a remainder in his beneficiaries. The present value of $E(1-t)$ to be received by the beneficiaries on the expected date of $T$ 's death is (from 2) 


$$
\frac{E}{D}(1-t),
$$

also given by (6a). This is the value for gift tax purposes of the transferred remainder. When taxed at the grossed-up tax rate (8) the gift tax liability is

$$
\left[\frac{E}{D}(1-t)\right]\left[\frac{t}{(1-t)}\right]=\frac{t E}{D}
$$

Since the transferred remainder is simply the present value of the anticipated estate after tax (from Case 1), and since it has been taxed consistently with the taxation at death of $E$ at rate $t$, the gift tax liability equals the present value of the anticipated estate tax liability in Case 1 (5a).

By incurring the gift tax associated with the current transfer, $T$ has depleted his initial wealth by $\frac{t E}{D}$. At death his estate for tax purposes is reduced by this amount, and also by the value (as of $T$ 's death) of the assets in which the remainder was created (date-of-gift value given by $6 \mathrm{a}$, date-of-death value given by 6 ). Thus, $T$ 's taxable estate (from 6,9 ) is

$$
E-E(1-t)-\frac{t E}{D}=t E\left(1-\frac{1}{D}\right) \text {, }
$$

which, under the assumptions of Case 2, represents assets actually passing to $T$ 's estate. The tax on this amount at rate $t$ is

$$
t^{2} E\left(1-\frac{1}{D}\right)
$$

and $T$ 's estate after tax (10 minus 11 and factoring) is

$$
(1-t) t E\left(1-\frac{1}{D}\right) \text {. }
$$

Valued as of death, the total pre-tax transfer by $T$, which includes the remainder created by gift (6a) valued at T's death (6), plus the gift tax (9) also valued as of T"s death (from 1, also given by 5), plus the taxable estate (10), is

$$
E(1-t)+t E+t E\left(1-\frac{1}{D}\right)=E+t E\left(1-\frac{1}{D}\right) .
$$

The aggregate transfer taxes paid, also valued as of T's death, which consist of the gift tax (9) valued as of death (from 1, also given by 5) plus the estate $\operatorname{tax}(11)$, is

$$
t E+t^{2} E\left(1-\frac{1}{D}\right)
$$

The total after-tax transfer to private beneficiaries, valued as of death (13 minus 14), is

$$
[1-t]\left[E+t E\left(1-\frac{1}{D}\right)\right] \text {. }
$$


By paying gift tax of $\frac{t E}{D}, T$ in effect chose to forego the income from those assets for his expected remaining life. The present value of that income interest (from 3 ) is

$$
\frac{t E}{D}\left(1-\frac{1}{D}\right)
$$

which has a value as of T's death (from 1) of

$$
t E\left(1-\frac{1}{D}\right)
$$

This equals the date-of-death value of the incremental pre-tax transfer that appeared in (13), on which tax was paid at rate $t$ (compare 14 with 5), yielding an incremental after-tax wealth transfer (from 15) of

$$
(1-t) t E\left(1-\frac{1}{D}\right)
$$

In other words, by paying himself a part of the taxes ultimately to be attracted by the transfer of his wealth, $T$ gave up part of the value attributable to his initial possession of wealth of $E$; what $T$ gave up was converted into an incremental transfer to his beneficiaries, the incremental wealth transfer was taxed at rate $t$, and the incremental wealth transfer after tax actually passed to $T$ 's beneficiaries.

The presence of additional assets in T's estate (10), even after creation by lifetime transfer of a remainder in $E(1-t)$, implies that $T$ could have made a lifetime transfer subject to a retained income interest in an amount greater than $E(1-t)$. If $X$ is the additional amount in which a remainder is created, the total value of the assets subject to the remainder would be $E(1-t)+X$. If so, the value for gift tax purposes of the remainder (from 2) would be

$$
\frac{E(1-t)+X}{D}
$$

the tax on which, at rate $\frac{t}{1-t}$, would be

$$
\frac{t E}{D}+\frac{t X}{D(1-t)}
$$

$T$ 's taxable estate now would consist of his original wealth $(E)$ minus the assets in which the remainder (19) was created, valued as of $T$ 's death (from 1), and minus the gift tax paid (20), or

$$
\begin{gathered}
E-[E(1-t+X)]-\left[\frac{t E}{D}+\frac{t X}{D(1-t)}\right] ; \text { or } \\
t E-\frac{t E}{D}-X-\frac{t X}{D(1-t)}, \text { or } \\
t E\left(1-\frac{1}{D}\right)-X\left[1+\frac{t}{D(1-t)}\right] .
\end{gathered}
$$

Suppose that $T$ 's desire was to maximize the amount in which, 
through a current transfer, he could create a remainder subject to an incone interest for his life. To do so (under the assumptions of Case 2) he would create interests in an amount such that the gift tax on the currently transferred remainder (at rate $\frac{t}{1-t}$ ), when added to the assets in which the remainder was created, would reduce his taxable estate (21) to zero. In that event

$$
X\left[1+\frac{t}{D(1-t)}\right]=t E\left(1-\frac{1}{D}\right)
$$

Rearranging and factoring yields

$$
X=t E\left[1-\frac{1}{D-t D+t}\right]
$$

As long as $X$ is greater than zero and less than the value given by (22), $T$ will leave some taxable estate (21) the tax on which (at rate $t$ ) will be

$$
\begin{gathered}
t^{2} E\left(1-\frac{1}{D}\right)-t X\left[1+\frac{t}{D(1-t)}\right], \text { or } \\
t\left[t E\left(1-\frac{1}{D}\right)-X\left[1+\frac{t}{D(1-t)}\right]\right],
\end{gathered}
$$

and $T$ 's estate after tax (21 minus 23$)$ will be

$$
[1-t]\left[t E\left(1-\frac{1}{D}\right)-X\left[1+\frac{t}{D(1 \dot{-})}\right]\right] \text {, }
$$

The total pre-tax transfer by $T$, valued as of $T$ 's death, consisting of the sum of the date-of-death value of the remainder created by gift (from 19 and 1), the date-of-death value of the gift tax paid (from 20 and 1), plus the taxable estate (21), is

$[E(1-t)+X]+\left[t E+\frac{t X}{1-t}\right]+t E\left(1-\frac{1}{D}\right)-X\left[1+\frac{t}{D(1-t)}\right]$. Rearranging and factoring yields

$$
E+t E\left(1-\frac{1}{D}\right)+\frac{t X}{(1-t)}\left(1-\frac{1}{D}\right) .
$$

The total tax paid by $T$ and his estate, also valued as of $T$ 's death, consisting of the sum of the gift tax (20) valued as of $T$ "s death (from 1), plus the estate tax (23), rearranged and factored, is

$$
t\left[E+t E\left(1-\frac{1}{D}\right)+\frac{t X}{(1-t)}\left(1-\frac{1}{D}\right)\right]
$$

and the total transfer to private beneficiaries after tax (25 minus 26) is

$$
[1-t]\left[E+t E\left(1-\frac{1}{D}\right)+\frac{t X}{(1-t)}\left(1-\frac{1}{D}\right)\right] \text {. }
$$

As before, creating a remainder in additional assets of $X$ has led to 
$T$ 's paying additional taxes, at rate $\frac{t}{1-t}$, on the present value of the additional remainder $\frac{X}{D}$, or $\frac{t X}{D(1-t)}$. By so doing, $T$ elected to forego an income interest for life in the amount of the additional gift tax paid. We should (again from 3) expect the additional interest $T$ has relinquished to have a present value of

$$
\frac{t X}{D(1-t)}\left(1-\frac{1}{D}\right)
$$

and a value as of T's death (from 1) of

$$
\frac{t X}{(1-t)}\left(1-\frac{1}{D}\right) \text {. }
$$

This corresponds with the date-of-death value of the incremental pre-tax transfer that materialized in T"s estate (compare 25 with 13), on which tax was paid at rate $t$ (compare 26 with 14), yielding an incremental aftertax transfer equal to the difference (compare 27 with 15). Since the expressions $\left(\frac{t}{1-t}\right)\left(1-\frac{1}{D}\right)$ and $\left(\frac{t^{t}}{1-t}\right)\left(1-\frac{1}{D}\right)$ are constant for given values of $t, i$, and $n$, we should expect the foregoing relationships to hold for all values of $X$ greater than zero and less than the value given by (22).

In other words, in a system in which estates and lifetime gifts are taxed consistently by taxing estates at rate $t$, and taxing net lifetime transfers to private beneficiaries when made at rate $\frac{t}{1-t}$, the impact on a transferor of making a lifetime gift subject to a retained life interest is that the transferor foregoes (assuming he restricts subsequent consumption to income) the income for life from the amount required to be paid as tax. The value of the interest foregone by the transferor shows up as an incremental wealth transfer to his beneficiaries. The incremental transfer is taxed at rate $t$. Only the interest foregone, after being taxed at rate $t$, is actually available for distribution to the transferor's beneficiaries. Under a system of grossed-up taxation, all transfers are taxed.

\section{Case 3: Lifetime Transfer Taxed Under Present Law; Gift Tax Taxed at Death}

As in Case 2, $T$ makes a lifetime transfer of assets equal to $E(1-t)$, retaining an income interest for life. The present value (and the value for gift tax purposes) of the transferred remainder $(6 a)$ is again $\frac{E}{D}(1-t)$. Under the assumptions of Case 3, however, the lifetime gift is taxed at the nominal transfer tax rate $(t)$, so that the gift tax is

$$
\frac{t E}{D}(1-t)
$$

Since, as in Case 2, the value of the remainder itself has been taxed, the date-of-death value of the assets in which the remainder was created, $E(1-t)$, will be excluded from T's estate, and, also as in Case 2, T's wealth will have been depleted by payment of the tax. Therefore the assets in $T$ 's estate will consist of his original wealth $(E)$ minus the date- 
of-death value of the assets in which the remainder was created (6) and tha gift $\operatorname{tax}(9 a)$, or

$$
\begin{gathered}
E-E(1-t)-\frac{t E}{D}(1-t), \text { or } \\
t E\left(1-\frac{1}{D}\right)+\frac{t^{2} E}{D}, \text { or } \\
t E-\frac{t E}{D}(1-t) .
\end{gathered}
$$

In Case 3, however, the gift tax itself is not taxed until T's death, when it is drawn back into $T$ 's estate under an unlimited version of section 2035(c). Thus, T's taxable estate also includes the gift tax paid (from $9 a$ ), and (adding $9 a$ and $10 a-1$ ) equals

$$
t E \text {, }
$$

the estate tax on which (at rate $t$ ) will be

$$
t^{2} E \text {. }
$$

The assets in T's estate after tax (10a-1 minus 11a) are

$$
t E-\frac{t E}{D}(1-t)-t^{2} E,
$$

which, rearranged and factored, equals

$$
(1-t) t E\left(1-\frac{1}{D}\right) \text {. }
$$

The value, as of $T$ "s death, of the total pre-tax wealth transfer, consisting of the sum of the remainder created by lifetime transfer (6a) valued as of death (6), plus the gift tax paid (9a) also valued as of death (from 1), plus the assets in T's estate (10a-1), equals

$$
\begin{gathered}
E(1-t)+t E(1-t)+t E-\frac{t E}{D}(1-t), \text { or } \\
E+t E\left(1-\frac{1}{D}\right)-t^{2} E\left(1-\frac{1}{D}\right), \text { or } \\
E+(1-t) t E\left(1-\frac{1}{D}\right) .
\end{gathered}
$$

On the other hand, for tax purposes, the total wealth transferred by $T$, valued as of $T$ 's death, consists of the lifetime gift valued as of death (6), plus the taxable estate (10a-2, which includes the amount of the gift tax paid, valued as of the time the gift was made), or

$$
\begin{gathered}
E(1-t)+t E, \text { or } \\
E .
\end{gathered}
$$


The total taxes paid, valued as of death, consist of the sum of the gift tax (9a) valued as of death (from 1), plus the estate tax (11a), or

$$
\begin{gathered}
t E(1-t)+t^{2} E, \text { or } \\
t E .
\end{gathered}
$$

The total transfer after tax, valued as of death, which may be derived either by valuing the remainder created by lifetime transfer as of T's death (6) and adding it to T's estate after tax (12a), or by subtracting the date-of-death value of the total taxes paid (14a) from the date-of-death value of the total pre-tax transfer $(13 a-1)$, is

$$
[1-t]\left[E+t E\left(1-\frac{1}{D}\right)\right] \text {. }
$$

In other words, the date-of-death value of the total pre-tax wealth transfer, as seen by the transfer tax system (13a-2), and thus the date-ofdeath value of the total transfer taxes paid (14a), correspond with the pre-tax transfer and transfer taxes paid in Case 1 ( 4 and 5). They are smaller by $t^{2} E\left(1-\frac{1}{D}\right)$ than the date-of-death value of the pre-tax transfer and transfer taxes paid in Case 2 (compare 13a-1 with 13, and 14a with 14). But the date-of-death value of the total wealth that actually passes to private beneficiaries after tax, given by (15a), corresponds with the date-of-death value of the aggregate wealth transferred after tax in Case 2 (15). In Case 3, then, as in Case 2, an incremental after-tax transfer has occurred, but in Case 3, in contrast with Case 2, the incremental transfer went untaxed.

A digression to explain these results is in order. In Case 1, the present values of T's life interest (7), the tax on T's estate (5a), and the amount passing to $T$ 's beneficiaries after tax (6a), were $E\left(1-\frac{1}{D}\right), \frac{t E}{D}$, and $\frac{E}{D}(1-t)$, respectively, the sum of which is $E$. In Case $2, \mathrm{~T}$ made a gift the present value of which was $\frac{E}{D}(1-t)$, incurring a gift tax of $\frac{t E}{D}(9)$. The present value of $T$ 's income interest therefore was reduced by $\frac{t E}{D}\left(1-\frac{1}{D}\right)(16)$, to (from 9,16$)$

$$
E\left(1-\frac{1}{D}\right)-\frac{t E}{D}\left(1-\frac{1}{D}\right) \text {. }
$$

The present value of the interest foregone by $T$ in turn reappeared as an asset of equivalent value (10, discounted to present value from 1 ) in his estate. The present value of the tax on that additional amount (11, discounted to present value), is $\frac{t^{2} E}{D}\left(1-\frac{1}{D}\right)$, leaving an estate after tax having a present value $\left(12\right.$, discounted to present value) of $(1-t) \frac{t E}{D}\left(1-\frac{1}{D}\right)$. These items-gift, gift tax, life interest, estate tax and estate after tax-have present values the sum of which is also $E$.

Essentially the same thing occurs in Case 3, with one difference: the government foregoes collecting part of the gift tax. Instead of collecting gift tax of 


$$
\left[\frac{E}{D}(1-t)\right]\left[\frac{t}{(1-t)}\right]=\frac{t E}{D}
$$

it collects $\frac{t E}{D}(1-t)(9 a)$. The left-hand side of (9) may be re-expressed by transforming $\frac{t}{1-t}$ into

$$
\begin{aligned}
& \frac{t^{2}+t-t^{2}}{(1-t)} \text {, or } \\
& \frac{t^{2}}{(1-t)}+t,
\end{aligned}
$$

and the gift tax liability in Case 2 can be expressed as

$$
\begin{gathered}
{\left[\frac{E}{\left.\left.D^{(1}-t\right)\right]}\left[\frac{t^{2}}{(1-t)}\right]+\frac{t E}{D}(1-t),\right. \text { or }} \\
\frac{t^{2} E}{D}+\frac{t E}{D}(1-t) .
\end{gathered}
$$

The gift tax collected in Case 2 but foregone in Case 3 (9, as restated, minus $9 a$ ) is therefore

$$
\frac{t^{2} E}{D}
$$

This tax is deferred, not forgiven: the estate tax in Case 3 (11a) of $t^{2} E$ turns out to exceed the estate tax in Case 2 (11) of $t^{2} E\left(1-\frac{1}{D}\right)$ by precisely the amount of the gift tax $\left(\frac{t E}{D}\right)$ foregone. Thus, in undiscounted terms, the total taxes collected are the same in both cases, namely

$$
t^{2} E+\frac{t E}{D}(1-t)
$$

but has been deferred for T's life. $T$ is permitted to retain, and the government foregoes, an interest for $T^{\prime}$ s life in $\frac{t^{2} E}{D}$, the present value of which (from 3) is

$$
\frac{t^{2} E}{D}\left(1-\frac{1}{D}\right)
$$

But what the government has foregone also has a value equal to the incremental tax of $\frac{t^{2} E}{D}\left(1-\frac{1}{D}\right)$ (11 discounted to present value) imposed on the incremental transfer with a present value of $\frac{t E}{D}\left(1-\frac{1}{D}\right)$ (10 discounted to present value) that occurred in Case 2. In other words, although the government has levied nominally identical transfer taxes in Cases 2 and 3, in the latter it has deferred imposition of a portion of them for a period such that the value foregone exactly offsets the tax on the additional transfer that occurs in both cases.

In Case 3, as in Case 2, the appearance of additional assets in T's estate (10a-1), even after the lifetime creation of a remainder in $E(1-t)$, implies that $T$ originally could have created a remainder sub- 
ject to a retained life interest in some greater amount, $E(1-t)+X$. If $T$ did so, the gift tax value of the remainder (given by 19), when taxed at the nominal rate $(t)$, would create a gift tax liability of

$$
\frac{t E}{D}(1-t)+\frac{t X}{D}
$$

The assets in T"s estate now would consist of his original wealth $(E)$, minus the assets in which the remainder was created (19), valued as of death (from 1), and minus the gift tax paid (20a), or

$$
t E-\frac{t E}{D}(1-t)-X-\frac{t X}{D}
$$

Under section 2035(c) (which is assumed to be in effect), however, $T^{\mathrm{s}} \mathrm{s}$ estate for tax purposes would also include the gift tax paid on creation of the remainder $(20 a)$, so that the taxable estate would be

$$
t E-X,
$$

the estate tax on which (at rate $t$ ) would be

$$
t^{2} E-t X,
$$

leaving an estate after tax (21a-1 minus 23a) of

$$
t E(1-t)-\frac{t E}{D}(1-t)-X(1-t)-\frac{t X}{D}
$$

In Case 3, $T$ cannot-at least if he is to be fair about it-increase the amount of the assets in which the remainder is created so that the sum of those assets plus the gift tax paid entirely depletes his wealth. The gift tax will be included in the estate for tax purposes, creating an estate tax liability.* Thus, to maximize the incremental wealth transfer fairly through the creation of a remainder by lifetime transfer, the assets in which the remainder is created should be limited to an amount such that, after paying gift tax on the creation of the remainder, $T$ will retain (and leave to his estate) assets sufficient to satisfy the estate tax on the sum of those assets plus the gift tax included in the estate under section 2035(c).

* To unify the gift and estate taxes by taxing the gift tax at death might; in other words, create something of an administrative problem. Provision might well have to be made for individuals not acting "fairly" and making lifetime transfers of remainders subject to retained life interests in an amount such that their estates were without sufficient assets to pay tax on the gift tax included in the estate under a version of I.R.C. $\S 2035$ (c) (1982) amended to reach all gift taxes paid during the taxpayer's life. Some form of transferee liability presumably would be the answer. Such an approach theoretically might give rise to income taxable to the transferor's estate. See Diedrich v. Commissioner, 457 U.S. 191, 197 (1982) (a "donor realizes an immediate economic benefit by the donee's assumption of the donor's legal obligation to pay the gift tax"); Old Colony Trust Co. v. Commissioner, 279 U.S. 716, 731 (1929) (employer's payment of income tax assessable against an employee constitutes additional income to such employee). 
In other words, in Case 2, $T$ maximizes the incremental transfer by reducing his taxable estate to zero; whereas, in Case 3 , he does so by reducing his estate after tax to zero. Setting (24a) equal to zero yields

$$
\begin{aligned}
& X\left(1-t+\frac{t}{D}\right)=t E-t^{2} E-\frac{t E}{D}+\frac{t^{2} E}{D}, \text { and } \\
& X\left(\frac{D-t D+t}{D}\right)=\frac{t E D-t^{2} E D+t^{2} E-t E}{D} .
\end{aligned}
$$

Factoring the right side and multiplying by $\frac{D}{D-t D+t}$ yields

$$
X=t E\left[1-\frac{1}{D-t D+t}\right]
$$

Since this expression is identical with expression 22, the maximum amount by which $T$ can increase the assets in which a remainder is created subject to a retained life interest, while providing for the satisfaction of transfer tax liabilities, is the same in Case 3 as in Case 2.

Provided that $X$ is greater than zero and less than the value given by 22, the date-of-death value of the total pre-tax wealth transfer, consisting of the assets in which the remainder (19) was created, valued as of death (from 1), plus the gift tax (20a) valued as of death (from 1), plus the assets in T's estate (21a-1), is

$$
\begin{gathered}
E(1-t)+X+t E(1-t)+t X+t E-\frac{t E}{D}(1-t)-X-\frac{t X}{D}, \text { or } \\
E+t E(1-t)\left(1-\frac{1}{D}\right)+t X\left(1-\frac{1}{D}\right) .
\end{gathered}
$$

However, for tax purposes the total wealth transferred by $T$, valued as of $T$ 's death, consists of the lifetime gift (19) valued as of death (from $1)$, plus the taxable estate (21a-2), or

$$
E(1-t)+X+t E-X, \text { or }
$$

$E$.

And the date-of-death value of the total transfer taxes paid, consisting of the gift tax (20a) valued as of death (from 1), plus the estate tax $(23 a)$, is

$$
t E(1-t)+t X+t^{2} E-t X, \text { or }
$$

$t E$.

The total transfer after tax, valued as of death, which again may be derived either by valuing the remainder created by lifetime transfer (19) as of T's death (from 1) and adding it to T's estate after tax (24a), or by subtracting the date-of-death value of the total taxes paid (26a) from the date-of-death value of the total pre-tax transfer (25a-1), is 


$$
[1-t]\left[E+t E\left(1-\frac{1}{D}\right)+\frac{t X}{(1-t)}\left(1-\frac{1}{D}\right)\right] \text {. }
$$

In other words, for all values of $X$ greater than zero and less than the value given by expression 22 , the total wealth transferred by $T$ will have a date-of-death value for tax purposes of $E$ (25a-2), equal to the value of $T$ 's estate in Case 1 (4). Consequently, in all such cases $T$ and T's estate will incur transfer tax liabilities having a date-of-death value of $t E$ (26a), identical to the estate tax paid in Case 1 (5). Nevertheless, for a given value of $X$, the total wealth transferred after tax in Case 3 (27a) will be identical to the total wealth transferred after tax for the corresponding value of $X$ in Case 2 (27). In both cases the same change occurs in the amount of the after-tax wealth transfer. But in Case 3 the value of the taxes paid does not reflect this change. 


\section{ApPENDIX B}

Two sets of steps are needed to create a rate schedule to be applied to the gift tax value of lifetime gifts that will operate to tax gifts in the same way as the rate table in I.R.C. $\S 2001$ (c) taxes estates.

First, a tax-exclusive gift tax rate, $t_{G}$, must be computed for each marginal, tax-inclusive estate tax rate, $t_{E 1}, t_{E 2}$, etc. The resulting gift tax rates are $t_{E 1} /\left(1-t_{E 1}\right), t_{E 2} /\left(1-t_{E 2}\right)$, etc.

Second, for the amount subject to tax in each estate tax marginal bracket, $B_{E 1}, B_{E 2}$, etc., there must be found a corresponding marginal gift $\operatorname{tax}$ bracket, $B_{G 1}, B_{G 2}$, etc., such that the width of each such bracket, $G_{1}$, $G_{2}$, etc., plus the tax on the amount taxed in that bracket, $G_{1}\left[t_{E 1} /\left(1-t_{E 1}\right)\right], G_{2}\left[t_{E 2} /\left(1-t_{E 2}\right)\right]$, etc., equals the width of the corresponding estate tax bracket.

Thus,

$$
\begin{gathered}
B_{G 1}=G_{1}: G_{1}+G_{1}\left[t_{E 1} /\left(1-t_{E 1}\right)\right]=B_{E 1} \\
G_{1}\left[1+t_{E 1} /\left(1-t_{E 1}\right)\right]=B_{E 1} \\
G_{1}\left[1 /\left(1-t_{E 1}\right)\right]=B_{E 1}, \text { and } \\
G_{1}=B_{E 1}\left(1-t_{E 1}\right)=B_{G 1}
\end{gathered}
$$

Successive creation of gift tax brackets in this fashion gives rise to a corresponding gift tax rate schedule. As so computed for the estate tax rate schedule as it will be in effect after 1984, the corresponding gift tax rate schedule is set out below. Note that, because the existing estate tax rates were fixed without regard for how readily they would convert into tax-exclusive gift tax rates, the gift tax rates emerge in decimal fractions. Such fractions have been rounded to the nearest one-hundredth.

The "tentative tax" referred to in the caption to the table below is the gift "tentative tax" referred to in I.R.C. \$ 2502(a)(1). The "tentative tax," as computed for estate tax purposes under I.R.C. § 2001(b)(1), would have to be modified to include in the amount with respect to which the tentative tax is computed, not only the decedent's "adjusted taxable gifts" and the decedent's taxable estate, but also the gift taxes paid by the decedent.

\section{RATE SCHEDULE}

AMOUNT WITH RESPECT TO

WHICH THE TENTATIVE TAX IS COMPUTED

Not over $\$ 8,200$

Over $\$ 8,200$ but not over $\$ 16,200$

Over $\$ 16,200$ but not over $\$ 31,800$

Tentative tax

$21.95 \%$ of such amount

$\$ 1,800$ plus $25 \%$ of the excess of such amount over $\$ 8,200$

$\$ 3,800$ plus $28.21 \%$ of the excess of such amount over $\$ 16,200$ 
Over $\$ 31,800$ but not over $\$ 47,000$

Over $\$ 47,000$ but not over $\$ 61,800$

Over $\$ 61,800$ but not over $\$ 76,200$

Over $\$ 76,200$ but not over $\$ 111,200$

Over $\$ 111,200$ but not over $\$ 179,200$

Over $\$ 179,200$ but not over $\$ 344,200$

Over $\$ 344,200$ but not over $\$ 501,700$

Over $\$ 501,700$ but not over $\$ 654,200$

Over $\$ 654,200$ but not over $\$ 801,700$

Over $\$ 801,700$ but not over $\$ 944,200$

Over $\$ 944,200$ but not over $\$ 1,219,200$

Over $\$ 1,219,200$ but not over $\$ 1,474,200$

Over $\$ 1,474,200$
$\$ 8,200$ plus $\$ 31.58 \%$ of the excess of such amount over $\$ 31,800$ $\$ 13,000$ plus $35.14 \%$ of the excess of such amount over $\$ 47,000$ $\$ 18,200$ plus $38.89 \%$ of the excess of such amount over $\$ 61,800$ $\$ 23,800$ plus $42.86 \%$ of the excess of such amount over $\$ 76,200$ $\$ 38,800$ plus $47.06 \%$ of the excess of such amount over $\$ 111,200$ $\$ 70,800$ plus $51.52 \%$ of the excess of such amount over $\$ 179,200$ $\$ 155,800$ plus $58.73 \%$ of the excess of such amount over $\$ 344,200$ $\$ 248,300$ plus $63.93 \%$ of the excess of such amount over $\$ 501,700$ $\$ 345,800$ plus $69.49 \%$ of the excess of such amount over $\$ 654,200$ $\$ 448,300$ plus $75.44 \%$ of the excess of such amount over $\$ 801,700$ $\$ 555,800$ plus $81.82 \%$ of the excess of such amount over $\$ 944,200$ $\$ 780,000$ plus $96.08 \%$ of the excess of such amount over $\$ 1,219,200$

$\$ 1,025,800$ plus $100 \%$ of the excess of such amount over $\$ 1,474,200$. 